\title{
MODIS-derived interannual variability of the equilibrium-line altitude across the Tibetan Plateau
}

\author{
Marinka SPIESS, ${ }^{1}$ Christoph SCHNEIDER, ${ }^{1}$ Fabien MAUSSION ${ }^{2}$ \\ ${ }^{1}$ Department of Geography, RWTH Aachen University, Aachen, Germany \\ ${ }^{2}$ Institute of Meteorology and Geophysics, University of Innsbruck, Innsbruck, Austria \\ Correspondence: Marinka Spieß <marinka.spiess@geo.rwth-aachen.de>
}

\begin{abstract}
Using the Moderate Resolution Imaging Spectroradiometer (MODIS) Level 1 radiance Swath Data (MOD02QKM) with a spatial resolution of $250 \mathrm{~m}$, we derive snowlines during JulySeptember 2001-12 for several mountain ranges distributed across the Tibetan Plateau (TP). Radiance bands 1 and 2 are projected to the study area and processed automatically. The discrimination between snow and ice is done using a k-mean cluster analysis and the snowlines are delineated based on a fixed percentile of the snow-cover altitude. The highest transient snowline altitude is then taken as a proxy for the equilibrium-line altitude (ELA). In the absence of measured glaciological, meteorological or hydrological data, our ELA time series enable better understanding of atmosphere-cryosphere couplings on the TP. Interannual ELA variability is linked to local and remote climate indices using a correlation analysis. Southerly flow and higher temperatures are linked with a higher ELA in most regions. Eastern and Trans-Himalayan sites show positive correlations between winter temperatures and ELA. As winter temperatures are substantially below zero, this suggests an enhancement of winter sublimation as opposed to a reduction in accumulation. It appears that large-scale atmospheric forcing has varying and sometimes opposite influences on the annual ELA in different regions on the TP.
\end{abstract}

KEYWORDS: atmosphere/ice/ocean interactions, glacier fluctuations, glacier mass balance, remote sensing, snow/ice surface processes

\section{INTRODUCTION}

The variability of the annual equilibrium-line altitude (ELA) is a valuable proxy for the variability of glacier mass balance (e.g. Zhang and others, 1998; Shea and others, 2013; Brun and others, 2015). In the absence of other measured glaciological, meteorological or hydrological data, the ELA could also be used to validate glaciological model results. The main objective of this study is to use remote-sensing approaches in order to compute the ELA for eight glacierized mountain ranges across the Tibetan Plateau (TP). These ELAs are then used to reveal differences in glacier response to the various climatic forcings on the TP, where only few and spatially dispersed mass-balance studies have been conducted to date.

The selected regions of interest (ROIs) are distributed heterogeneously across the TP, spanning an east-to-west transect (Fig. 1). The eight study sites are: the Purogangri ice cap on the central TP, two regions in the western Nyainqêntanglha range, the Targo Gangri, Shankangsham and Surla ranges in the south-central TP, the Gurla Mandhata massif in the southwest and the Muztagh Ata in the west of the TP (Fig. 1).

The area of the TP covers different climate regions with distinct influences on glaciers. In simplified terms: (1) the precipitation and temperature decreases from the southeast to the central western plateau, (2) the accumulation regime changes from summer-accumulation type in the east to winter-accumulation type in the west, and (3) the glacier types change from temperate in the southeast to polythermal and cold glaciers in the continental west (Shi and Liu, 2000; Rupper and Roe, 2008; Maussion and others, 2014). All lakes fed from glaciers in the ROls show increased water levels between 2003 and 2009, which seems to be induced by increased precipitation rates as well as by glacier meltwater (Zhang and others, 2011; Wu and others, 2014). Wu and others (2014) found that glacier melt contributed $21 \%$ of the recent increase in the volume of Nam Co lake. Except for the southeastern slope of the Nyainqêntanglha range, none of the ROIs has an outflow to the sea (e.g. Neckel and others, 2013).

\section{STUDY SITES}

The Purogangri ice cap (PIC) is Tibet's largest ice cap in the semi-arid central plateau (Fig. 2; Table 1). Its glaciers have a spring and summer accumulation regime. The region receives $\sim 70 \%$ of its precipitation between May and September (Fig. 3) and is influenced by strong westerly winds during winter (Maussion and others, 2014). Neckel and others (2013) found the recent PIC geodetic mass budget to be close to equilibrium, with a mass balance of $-44 \pm 15 \mathrm{~mm}$ w.e. $\mathrm{a}^{-1}$ between 2000 and 2012.

The western Nyainqêntanglha range is located in the southern central TP at the transition zone between temperate and subcontinental glaciers (Bolch and others, 2010; Fig. 2; Table 1). It is influenced by westerlies in winter but has a distinct summer accumulation regime in connection with the Indian monsoon. More than $90 \%$ of annual precipitation falls between May and September (Fig. 3). We differentiate two ROls in the western Nyainqêntanglha range to take into account distinctly different synoptic climatology on the two sides of the hydrological divide: a northwest-oriented slope $(\mathrm{NWN}$ ) and a southeast-oriented slope (SEN; Fig. 2). The glaciers in the NWN drain into Nam Co lake. The glaciers on 


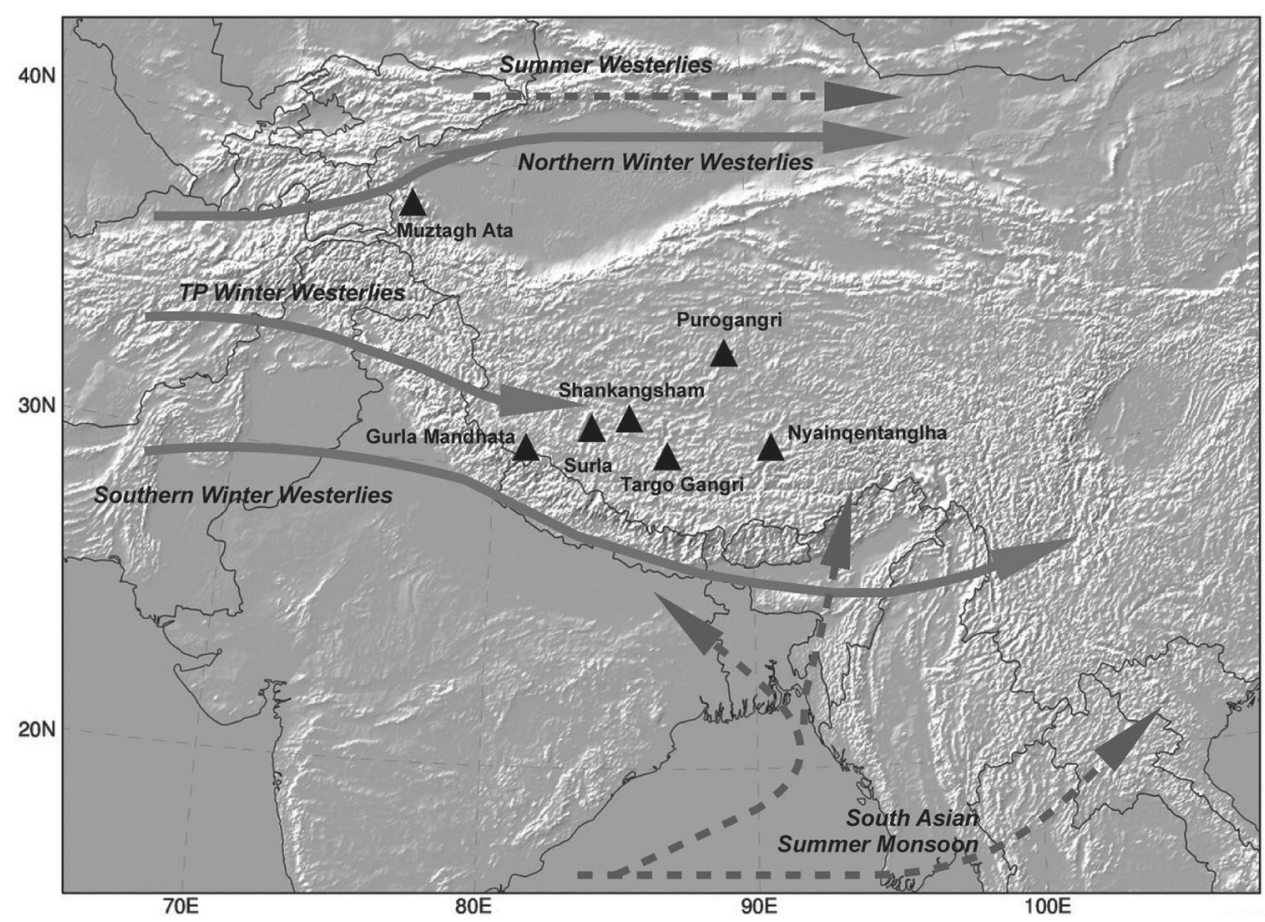

Fig. 1. The Tibetan Plateau (TP). Study areas (ROIs) are indicated as triangles. SEN and NWN in the western Nyainqêntanglha together are represented as one triangle. Arrows indicate the basic atmospheric circulation, based on Bolch and others (2012) and Yao and others (2014).

the southeastern slope drain eventually to the TsangpoBrahmaputra River (Yao and others, 2008). The ice cover in SEN reaches higher than on NWN (Table 1) but both slopes showed similar glacier change rates (Bolch and others, 2010). Total glacier area decreased by $-9.9 \pm 3.1 \%$ between 1976 and 2009 and no glacier was found to be advancing. Mean glacier surface elevation changes of $-8.39 \mathrm{~m}$ from Ice, Cloud and land Elevation Satellite (ICESat) and Shuttle Radar Topography Mission (SRTM) data were found between 2003 and 2009 in the western Nyainqêntanglha range (Wu and others, 2014). Zhao and others (2014) studied Gurenhekou glacier as representative of the southern slope of the Nyainqêntanglha range, and found an average retreat rate of $8.3 \mathrm{~m} \mathrm{a}^{-1}$. Mölg and others (2013) calculated the 2001-11 mass balance of Zhadang glacier in the western Nyainqêntanglha range using a physically based model. They detected mid-latitude climate as a possible driver of glacier massbalance variability in this region.

Extending the transect to the west, we chose to add three ROls in the central Trans-Himalaya. These glaciers belong to the subcontinental and the extreme continental type. The mountain range, south of Tangra Yumco lake, is called Targo Gangri in the following, as mentioned by Hedin (1909) (Fig. 2; Table 1). Further, we chose the southernmost part of the Shankangsham range (Fig. 2; Table 1) which is mentioned by Town (2008). Its glaciers drain into Dawa lake to their south. Glaciers in the Surla range (Styron and others, 2013) drain into the Rinchen Tshubsu in the north and, to a lesser extent, into Palung $\mathrm{Co}$ in the southeast (Fig. 2; Table 1). The glaciers in all three ROls belong to a pronounced summer accumulation regime type, receiving up to $70 \%$ of its annual precipitation in June to August (Fig. 3). Absolute values of annual precipitation within the High Asia Refined reanalysis (HAR) dataset must be cautiously interpreted (Huintjes, 2014). They range well below $500 \mathrm{~mm}$ for all three ROls.
The Gurla Mandhata or Naimona'nyi massif is located in the southwestern TP (Fig. 2; Table 1), an area of monsoonal and westerlies influence. Here a summer accumulation regime with a second precipitation maximum in February is identifiable (cf. Maussion and others, 2014). Ye and others (2009) found an increasing glacier shrinkage in the Gurla Mandhata massif of $0.77 \mathrm{~km}^{2} \mathrm{a}^{-1}$ from 1999 to 2003. Tian and others (2014) find a stronger thinning at Naimona'nyi glacier in the Gurla Mandhata massif between 2008 and $2010(-1.34 \mathrm{~m})$ than between 2010 and $2013(-0.87 \mathrm{~m})$, probably due to more than average precipitation in the latter years.

The Muztagh Ata massif is located in the eastern Pamirs (Fig. 1). In the western margin of the TP, the monsoon influence (if any) is very weak. The westerlies are predominant, with a precipitation maximum in spring (Maussion and others, 2014). The glaciers belong to the extreme continental or cold glacier type (Huintjes, 2014).

Huintjes (2014) calculated the mass balance of the PIC, Zhadang glacier, Muztagh Ata glacier and Naimona'nyi glacier in the Gurla Mandhata range from 2001 to 2012 using a physically based energy-balance model. Yao and others (2012) derived annual mass balances from in situ measurements for Muztagh Ata glacier (2002, 2003, 2006, 2008 and 2010) and Naimona'nyi glacier in the Gurla Mandhata massif (2006, 2008, 2009 and 2010), among others. Glacier mass loss generally decreases from the Himalaya to the continental interior, with slightly positive mass balances observed on Muztagh Ata glacier in the eastern Pamir. Glacier thickness changes for the entire Pamir-Karakoram-Himalaya arc between 2003 and 2008 (Kääb and others, 2015) show lowering in eastern Nyainqêntanglha and the Gurla Mandhata region, but a slight thickening for the Gurla Mandhata region and even a slight thickness increase of up to $0.15 \mathrm{~m} \mathrm{a}^{-1}$ for the easternmost Pamir comprising Muztagh Ata. 

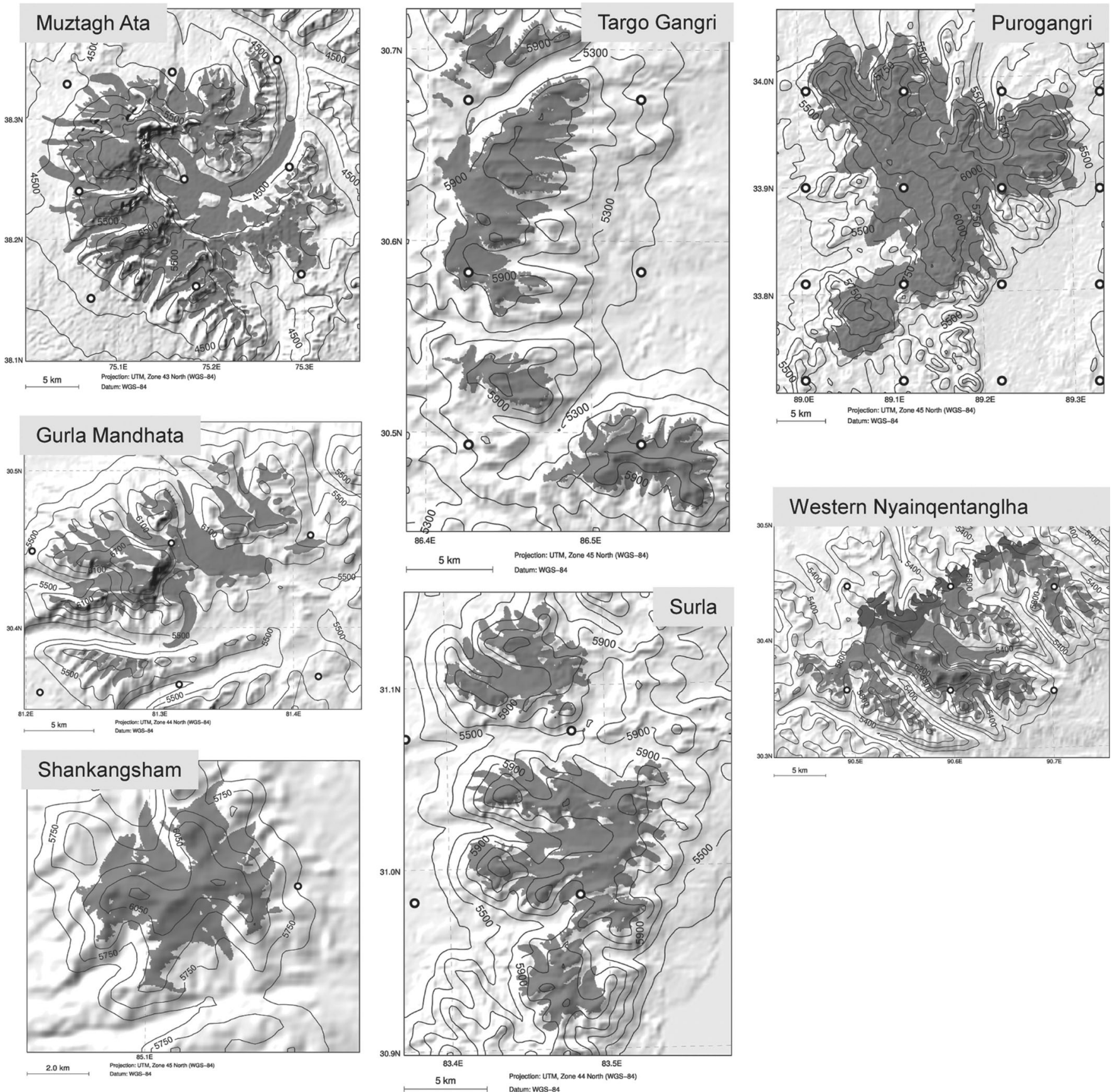

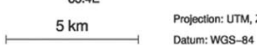

Fig. 2. Topographic maps of all ROIs, with glacier masks in grey. SEN and NWN are combined into one plot, with NWN in darker grey. Elevations are given in ma.s.I. HAR gridpoints as circles.

\section{DATA \\ MODIS data}

We use the Terra and Aqua Level 1B Collection 05 MODIS (Moderate Resolution Imaging Spectroradiometer) swath data (MOD02QKM and MYD02QKM) with radiance calibrated on board and global coverage every 1-2 days. The dataset provides calibrated and quality-assessed radiance. We work with band 1 (visible light, 620-670 nm) and band 2 (near-infrared, $841-876 \mathrm{~nm}$ ) which are provided at a spatial resolution of $250 \mathrm{~m}$. The Terra (Aqua) satellite crosses the TP around noon (in the afternoon) at local solar time (Hall and others, 2006). We used Terra (Aqua) data from 1 July to 30 September in the years 2001 (2002) to 2012 (2012). We utilized the cloud mask provided in the Terra and Aqua snow-cover level 2 swath data (MOD10L2 and MYD10L2) with a $500 \mathrm{~m}$ resolution (Hall and others, 2006).

\section{ASTER digital elevation model and glacier mask}

Terrain elevations were derived from the ASTER Global Digital Elevation Model (GDEM), Version 2 available at the NASA Land Processes Distributed Active Archive Center as a contribution of METI (Ministry of Economy, Trade and Industry, Japan) and NASA. Its spatial resolution is $30 \mathrm{~m}$. For each ROI, ASTER data were resampled to $250 \mathrm{~m}$ resolution using the nearest-neighbour method and co-registered with the MODIS scenes to derive a single altitude per MODIS pixel. For calculation we considered MODIS pixels located in the glacier masks derived from the glacier outlines. The PIC glacier mask was obtained from Neckel and others 

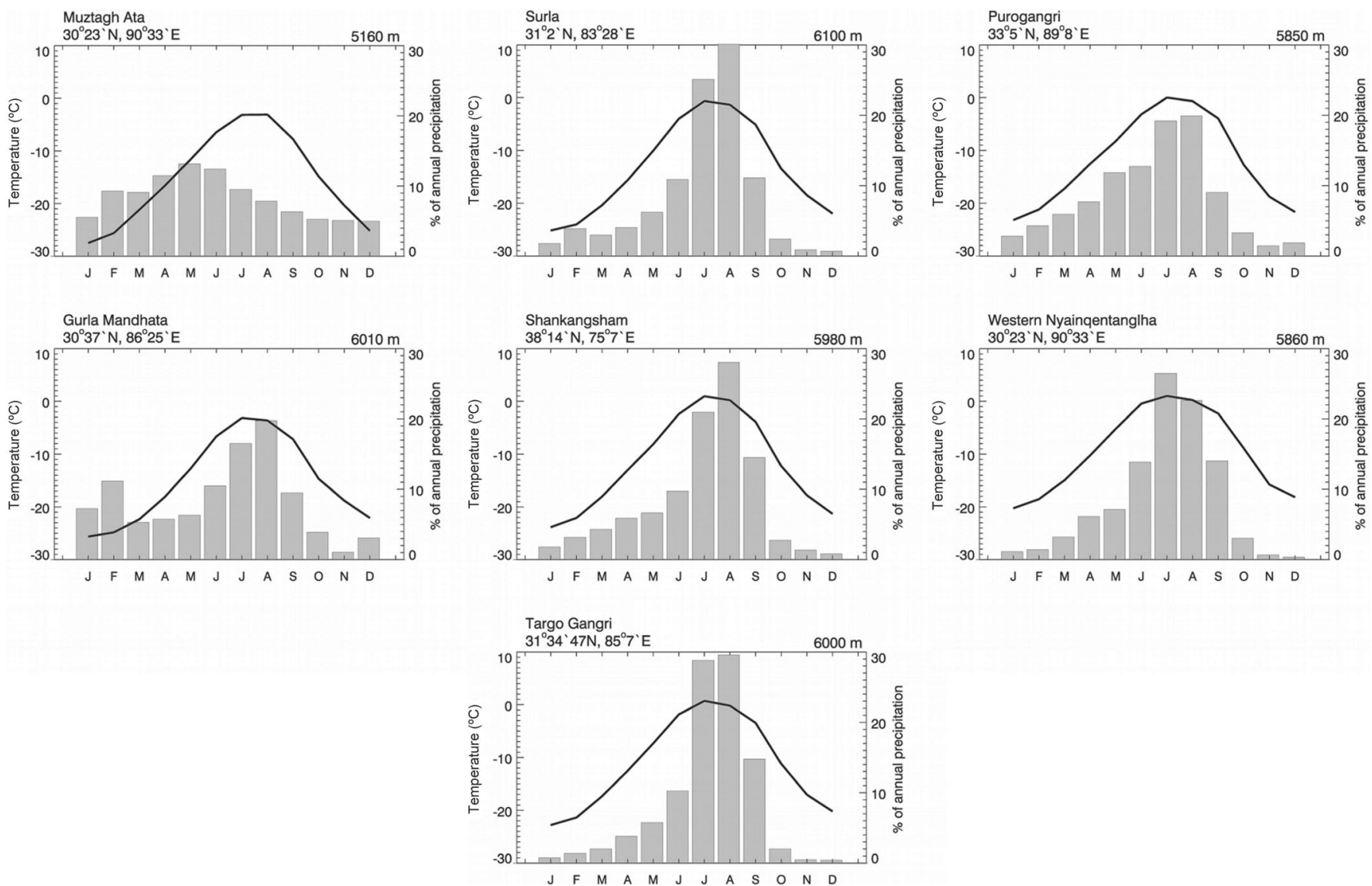

Fig. 3. Average annual cycle of temperature and of precipitation as percentage of the total annual precipitation for all ROls.

(2013). The masks for the Nyainqêntanglha range were taken from the Randolph Glacier Inventory (RGl; Pfeffer and others, 2014) Version 3.2, available at http://www.glims. org/RGl/. In this particular region the RGI glacier masks proved to be very accurate compared to the older Chinese glacier inventory (CGI) (Bolch and others, 2010). The glacier masks for the regions of Targo Gangri, Surla and Shankangsham (personal communication from T. Bolch, 2014) were derived by a threshold approach on a Landsat band ratio (band 3/band 5). The glacier masks of the Gurla Mandhata and Muztagh Ata massif from 2000 were provided by Nicolai Holzer of the Dresden University of Technology, Germany.

\section{Climate data}

Mean monthly climate data at $10 \mathrm{~km}$ resolution were obtained from the High Asia Refined reanalysis data (HAR10; Maussion and others, 2014, http://www.klima.tuberlin.de/HAR). For each ROI, an area covering the extent of the glacierized area plus a one-pixel margin is considered (Fig. 2). We selected the climate variables for their possible direct $\left(2 \mathrm{~m}\right.$ air temperature $\left({ }^{\circ} \mathrm{C}\right)$ and precipitation $\left.\left(\mathrm{mm} \mathrm{h}^{-1}\right)\right)$ or indirect (wind speed $\left(\mathrm{m} \mathrm{s}^{-1}\right)$, meridional and zonal component at $10 \mathrm{~m}$ above ground, $400 \mathrm{hPa}$ and $300 \mathrm{hPa}$ levels) influence on glacier mass balance.

To study large-scale climatic controls we used several standard teleconnection indices. The Hurrell North Atlantic Oscillation (NAO) index is defined as sea-level pressure differences over the Atlantic sector (Fig. 5). It is provided by the Climate Data Guide of the US National Center for Atmospheric Research (NCAR) University Corporation for
Atmospheric Research (UCAR) (https://climatedataguide. ucar.edu/climate-data/hurrell-north-atlantic-oscillation-naoindex-pc-based). The Indian summer monsoon (ISM) index is defined as the difference in the zonal wind speed at the $850 \mathrm{hPa}$ level between $5-15^{\circ} \mathrm{N}, 40-80^{\circ} \mathrm{E}$ and $20-30^{\circ} \mathrm{N}, 70$ $90^{\circ} \mathrm{E}$. It was obtained from the Asia Pacific Data Research Centre (APDRC, http://apdrc. soest.hawaii. edu/projects/ monsoon/seasonal-monidx.html, 13 May 2014). The Southern Oscillation (SO), Arctic Oscillation (AO), Polar/Eurasia (POL), East Atlantic/Western Russia (EAWR), West Pacific (WP) and Pacific/North America (PNA) all present differences in sea-level pressure as shown in Figure 5. The multivariate ENSO index (MEI) includes six variables over the tropical Pacific to capture the ocean-atmosphere coupling of the El Niño Southern Oscillation (ENSO) phenomenon. The latter seven indices are obtained from the US National Oceanic and Atmospheric Administration (NOAA) Climate Prediction Center, available at http://www.cpc. ncep.noaa.gov/. The dipole mode index (DMI) is defined as a gradient between the sea surface temperature in the western and the eastern equatorial Indian Ocean (Fig. 5), obtained from the Japan Agency for Marine Earth Science and Technology, at http://www.jamstec.go.jp/.

\section{METHODS}

\section{Preprocessing}

The swath data were projected using the ENVI plug-in MODIS Conversion Toolkit (MCTK) providing automatic bow-tie correction. The reflectance data are returned as dimensionless numbers between 0.0 and 1.0. The 
Table 1. Overview of spatial data and climate data of all study regions (MA: Muztagh Ata; GM: Gurla Mandhata; S: Surla; Sh: Shankangsham; TG: Targo Gangri; PIC: Purogangri ice cap; NWN: northwest-oriented slope; SEN: southeast-oriented slope). t2 is standard deviation of temperature at $2 \mathrm{~m}$ above ground

\begin{tabular}{|c|c|c|c|c|c|c|c|c|}
\hline ROI & MA & GM & $S$ & Sh & TG & $\mathrm{PIC}$ & NWN & SEN \\
\hline Location & $\begin{array}{l}38^{\circ} 14^{\prime \prime} \mathrm{N} \\
75^{\circ} 7^{\prime} \mathrm{E}\end{array}$ & $\begin{array}{l}30^{\circ} 25^{\prime} \mathrm{N} \\
81^{\circ} 19^{\prime} \mathrm{E}\end{array}$ & $\begin{array}{l}31^{\circ} 2^{\prime} \mathrm{N} \\
83^{\circ} 28^{\prime} \mathrm{E}\end{array}$ & $\begin{array}{l}31^{\circ} 34^{\prime} \mathrm{N} \\
85^{\circ} 7^{\prime} \mathrm{E}\end{array}$ & $\begin{array}{l}30^{\circ} 37^{\prime} \mathrm{N} \\
86^{\circ} 25^{\prime} \mathrm{E}\end{array}$ & $\begin{array}{l}33^{\circ} 54^{\prime} \mathrm{N} \\
89^{\circ} 8^{\prime} \mathrm{E}\end{array}$ & $\begin{array}{l}30^{\circ} 41^{\prime} \mathrm{N} \\
90^{\circ} 6^{\prime} \mathrm{E}\end{array}$ & $\begin{array}{l}30^{\circ} 4 \mathrm{~N} \\
90^{\circ} 6^{\prime} \mathrm{E}\end{array}$ \\
\hline Area $\left(\mathrm{km}^{2}\right)$ & 284 & 72.9 & 75 & 10,8 & 97 & 397 & 31 & 135 \\
\hline Number of pixels & 4546 & 1089 & 1651 & 309 & 1455 & 6362 & 465 & 2025 \\
\hline Median altitude (m) & 5160 & 6010 & 6100 & 5980 & 6010 & 5850 & 5810 & 5860 \\
\hline Elevation range $(\mathrm{m})$ & 3600 & 2300 & 1000 & 700 & 1000 & 1200 & 1100 & 1800 \\
\hline MOD02QKM processable (\%) & 41 & 22 & 26 & 20 & 27 & 33 & 25 & 24 \\
\hline $\begin{array}{l}\text { Total number of scenes available } \\
\text { for calculation }\end{array}$ & 957 & 435 & 536 & 427 & 545 & 709 & 504 & 489 \\
\hline $\begin{array}{l}\text { Mean transient snowline altitude, } \\
\text { Jul-Sep }(m)\end{array}$ & 4889 & 5895 & 5960 & 5841 & 5841 & 5687 & 5698 & 5742 \\
\hline $\begin{array}{l}\text { Mean std dev. of transient snowline, } \\
\text { Jul-Sep }(m)\end{array}$ & 95 & 54 & 27 & 37 & 24 & 37 & 45 & 37 \\
\hline $\begin{array}{l}\text { Std dev. of interannual median } \\
\text { of transient snowline }\end{array}$ & 37 & 30 & 9 & 16 & 13 & 11 & 18 & 10 \\
\hline Range ELA $(\mathrm{m})$ & $5018-5303$ & $5923-6001$ & $5972-6042$ & $5875-5941$ & $5856-5914$ & $5705-5800$ & $5728-5814$ & $5766-5829$ \\
\hline Mean ELA (m) & 5130 & 5944 & 5997 & 5914 & 5888 & 5761 & 5784 & 5792 \\
\hline Std dev. of ELA & 90.6 & 23.3 & 23.2 & 21.3 & 21 & 27.8 & 29.6 & 22.2 \\
\hline Mean error of ELA & 83.6 & 43.8 & 38.8 & 34.4 & 41.6 & 40.6 & 31.1 & 35.8 \\
\hline Avg. glacier slope $\left(^{\circ}\right)$ & 8 & 6.4 & 7.3 & 9 & 10.3 & 5.1 & 6.3 & 8.2 \\
\hline Mean precip. $\left(\mathrm{mm} \mathrm{a}^{-1}\right)$ & 583 & 786 & 477 & 507 & 390 & 595 & 643 & 675 \\
\hline $\begin{array}{l}\text { Std dev. annual precip. } \\
\text { (glaciological year) }\end{array}$ & 71 & 162 & 134 & 114 & 109 & 75 & 129 & 141 \\
\hline Std dev. t2 Dec & 1.2 & 1.1 & 1.1 & 1.3 & 1.26 & 1.3 & 1.2 & 1.3 \\
\hline Std dev. t2 Feb & 2.1 & 1.5 & 1.9 & 1.5 & 1.6 & 1.8 & 1.5 & 1.5 \\
\hline Std dev. t2 Jun & 1.4 & 1.0 & 0.7 & 0.7 & 0.6 & 1 & 0.8 & 0.8 \\
\hline Std dev. t2 Aug & 1.0 & 0.4 & 0.5 & 0.7 & 0.6 & 0.9 & 0.6 & 0.6 \\
\hline Std dev. precip. Dec & 12 & 13 & 3 & 3 & 2 & 5 & 2 & 2 \\
\hline Std dev. precip. Feb & 26 & 57 & 16 & 12 & 3 & 7 & 7 & 7 \\
\hline Std dev. precip. Jun & 33 & 57 & 41 & 39 & 34 & 30 & 34 & 37 \\
\hline Std dev. precip. Aug & 25 & 79 & 56 & 54 & 42 & 34 & 45 & 48 \\
\hline $\begin{array}{l}\text { Mean wind speed }\left(\mathrm{m} \mathrm{s}^{-1}\right) \\
(400 \mathrm{hPa} \text {, Jul- Sep) }\end{array}$ & 16.2 & 4.9 & 5.4 & 6.8 & 4.6 & 10.2 & 4.2 & 4.3 \\
\hline Mean precip. (mm month ${ }^{-1}$ ) (Jul-Sep) & 47 & 116 & 105 & 111 & 95 & 95 & 137 & 145 \\
\hline
\end{tabular}

Table 2. Comparison of the classified snow pixels area ratio (SAR), regional mean (MSA) and standard deviation $(\sigma)$ of snowline altitudes of the ROIs Surla (S), Shankangsham (Sh), Gurla Mandhata (GM) and PIC from MODIS and Landsat satellite data

\begin{tabular}{|c|c|c|c|c|}
\hline & S & Sh & GM & $\mathrm{PIC}$ \\
\hline Acquisition date & 7 Aug 2011 & 27 Sep 2009 & 3 Sep 2004 & 15 Aug 2010 \\
\hline Valid pixel (\%) & 56 & 100 & 99 & 94 \\
\hline \multicolumn{5}{|l|}{ Landsat } \\
\hline Path/row & $143 / 39$ & $142 / 43$ & $144 / 39$ & $140 / 36$ \\
\hline Sensor & TM 4/5 & TM 4/5 & L 7 ETM+ & TM 4/5 \\
\hline SAR & 0.45 & 0.67 & 0.58 & 0.61 \\
\hline MSA (m) & 5880 & 5870 & 5891 & 5774 \\
\hline \multicolumn{5}{|l|}{ MODIS } \\
\hline SAR & 0.40 & 0.52 & 0.61 & 0.61 \\
\hline $\begin{array}{l}\text { MSA 20th per- } \\
\text { centile }(\mathrm{m})\end{array}$ & 5995 & 5905 & 5943 & 5828 \\
\hline $\begin{array}{l}\text { MSA 14th per- } \\
\text { centile }(\mathrm{m})\end{array}$ & 5965 & 5871 & 5896 & 5797 \\
\hline $\begin{array}{l}\text { MSA 13th per- } \\
\text { centile }(\mathrm{m})\end{array}$ & 5953 & 5870 & 5893 & 5790 \\
\hline $\begin{array}{l}\text { MSA 12th per- } \\
\text { centile }(\mathrm{m})\end{array}$ & 5948 & 5865 & 5890 & 5784 \\
\hline $\begin{array}{l}\text { MSA 10th per- } \\
\text { centile }(\mathrm{m})\end{array}$ & 5934 & 5857 & 5866 & 5768 \\
\hline$\sigma(\mathrm{m})$ & 22.99 & 18.41 & 28.02 & 22.10 \\
\hline
\end{tabular}

snow-cover data were resampled to a $250 \mathrm{~m}$ resolution using nearest-neighbour interpolation, and the binary cloud mask was extracted subsequently. For every ROI, we saved each Terra and Aqua reflectance scene, together with the respective glacier mask, DEM and cloud mask. Each scene was then screened for quality assessment.

\section{Snow/ice classification and transient snowline altitude}

Considering the data within the glacier mask, we first applied the cloud mask and excluded erroneous pixels and scenes with linear distortions. After applying a spatial cloud filter (Spieß and others, 2015) scenes with $<45 \%$ data coverage were excluded.

To differentiate snow and ice surfaces, a k-means cluster analysis was performed (cf. Shea and others, 2013). The result was monitored to exclude scenes which are fully snow-covered and not suitable for a cluster analysis.

The mean altitude of the transient snowline was taken as the 13th percentile of the snow-covered altitudes, following a similar approach to that of Shea and others (2013). In our earlier study using MODIS $500 \mathrm{~m}$ data at PIC, the absolute altitude using this threshold was validated against Landsat imagery (Spieß and others, 2015). For this study, four cloudfree Landsat images could be used for validation (Table 2; Fig. 4). The number of scenes is limited because the 

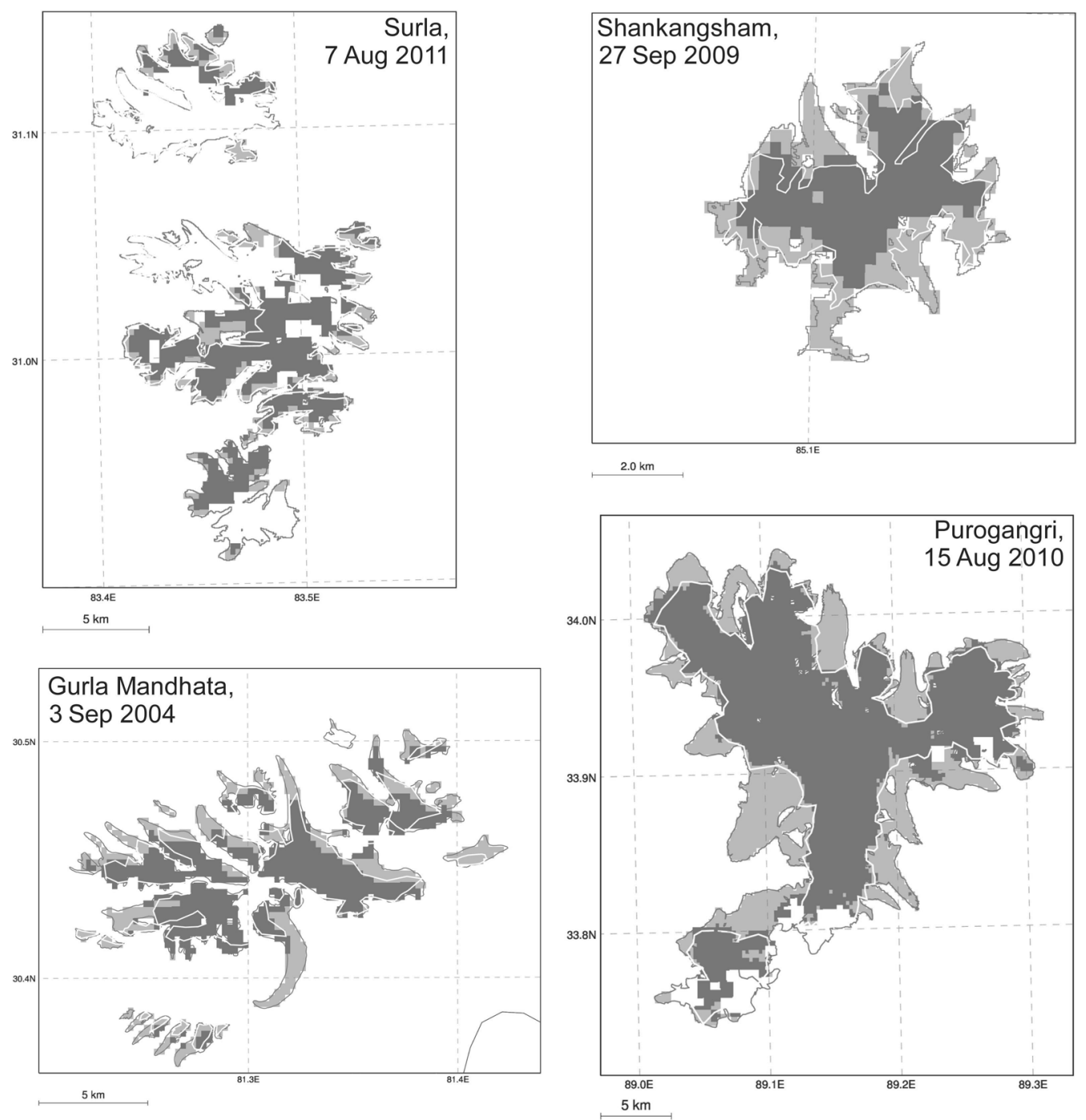

Fig. 4. MODIS snow (dark grey) and ice (light grey) pixels; digitized snowline from Landsat image (white line) within the glacier mask.

snowline has to be clearly visible and a MODIS scene with enough valid pixels has to be available for the corresponding acquisition date. A snow pixel area ratio (SAR = A_snow/A_total) was calculated for Landsat and MODIS scenes, and the altitude of the digitized Landsat snowline was compared to the corresponding daily MODIS snowline altitude (Table 2).

Within these four scenes the mean difference between the SAR of Landsat and the SAR of MODIS is minor (Table 2). The mean difference between the mean snowline altitude (MSA) of Landsat and the 13th percentile of MODIS snow pixel is $23 \mathrm{~m}$. The Surla scene displays the largest discrepancy, with the MODIS-derived MSA being $73 \mathrm{~m}$ higher than the Landsat-derived MSA. This can be ascribed to the poor MODIS data coverage of $56 \%$. To account for the fact that incomplete data coverage of the single scene might result in overestimation of the highest snowline altitude, the transient snowline altitudes are weighted by the percentage of the underlying data coverage (cf. Shea and others, 2013). In the considered Surla scene the MSA difference is thus reduced to $39 \mathrm{~m}$ after weighting. Varying the selected percentile between 10th and 20th leads to an absolute change of $61 \mathrm{~m}$ but it affects the variability of the ELA only negligibly (Spieß and others, 2015).

\section{Equilibrium-line altitude}

Provided a required minimum of 10 days holding valid reflectance data during the observation period is reached, the resulting highest position of the transient snowline within the ablation period is taken as the ELA proxy. This approach differs slightly from those of other authors: Shea and others (2013) who used the maxima from a loesssmoothed time series of transient snowline elevations; Mernild and others (2013) who used a second-order polynomial regression to estimate the highest position of the transient snowline; and Dumont and others (2012) and Brun and others (2015) who used the minimum albedo value to estimate the annual mass balance. The average annual cycle of albedo derived from the MODIS snow product data for Purogangri, Gurla Mandhata and Targo Gangri shows its minimum within this period from July to September, even though the albedo also considerably declines during winter when there is little ablation but also no accumulation. We used the same set of parameters for all ROIs to obtain a comparable proxy for the variability of the ELA, rather than aiming at retrieving true absolute altitudes.

\section{ELA and climate}

Finally, a single linear correlation analysis was performed in order to relate the interannual variability of the annual ELA 


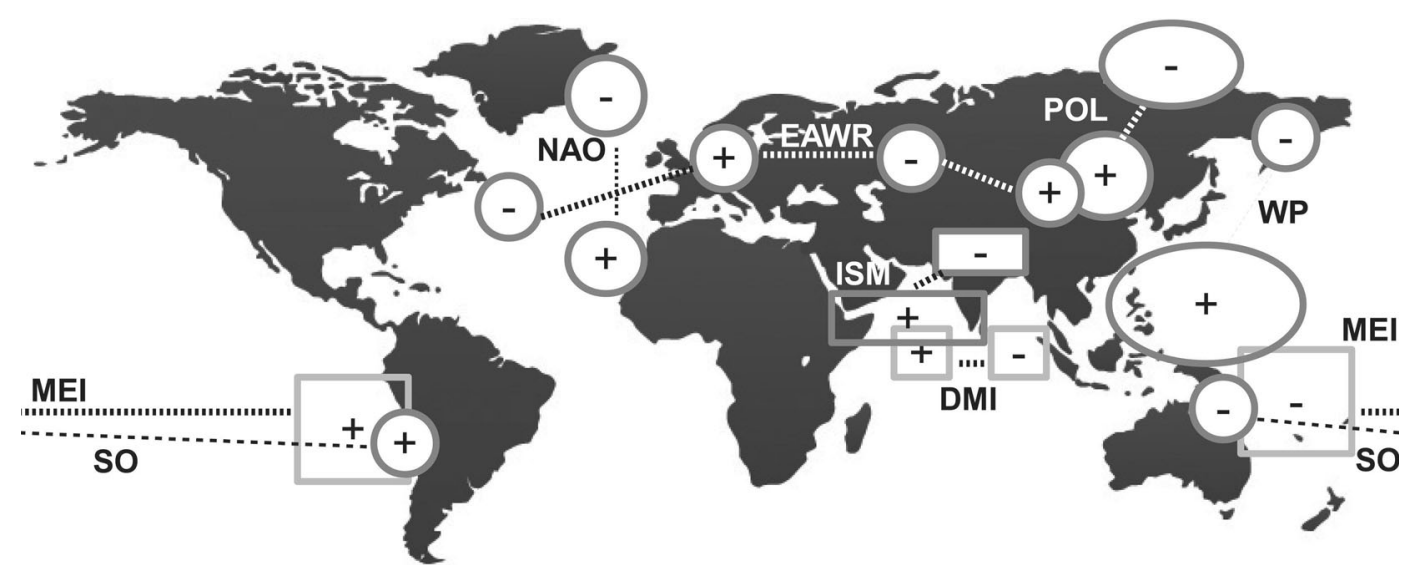

Fig. 5. Locations of action of the considered circulation indices; sea-level pressure (circle) or sea surface temperature (DMI), multivariate variables (MEI) or zonal wind (ISM) (box) anomalies. The signs indicate the anomalies during the respective positive phase.

to the underlying climate forcing represented by various monthly predictors and teleconnection indices as introduced in the data section. The correlations refer to conditions during the glaciological year from October of the preceding calendar year until September of the actual year (Spieß and others, 2015).

\section{RESULTS}

\section{Transient snowline altitude}

The transient snowline altitudes for all ROIs (Figs 6a, 7a, 8a and $9 \mathrm{a}$ ) are presented as yearly boxplots. The mean transient snowline altitude as well as the mean annual ELA is lowest at Muztagh Ata $(4889 \mathrm{~m}, 5130 \mathrm{~m})$ and highest at Surla (5960 m, $5997 \mathrm{~m})$ (Table 1). The mean standard deviation of yearly transient snowline ranges from $24 \mathrm{~m}$ at Targo Gangri to $97 \mathrm{~m}$ at Muztagh Ata. The standard deviation of the annual median transient snowline ranges from $9 \mathrm{~m}$ at Surla to $37 \mathrm{~m}$ at Muztagh Ata.

\section{Equilbrium-line altitude}

Interannual ELA proxies are shown in Figures $6 \mathrm{~b}, 7 \mathrm{~b}, 8 \mathrm{~b}$ and 9b. Uncertainty in the estimated ELA is related to the percentile used to calculate the transient snowline altitude, which was varied in this study between 10th and 16th. The errors range between 31 and $84 \mathrm{~m}$. The year 2001 does not allow calculation of the ELA proxy in most ROIs because the required minimum of 10 days with valid reflectance data during the observation period is not reached. In Figure 8b the interannual variability of the ELA proxy resulting from a previous method based on $500 \mathrm{~m}$ spatial resolution MODIS data (Spieß and others, 2015) is added for PIC. Both time series are highly and significantly correlated $(r=0.91)$, showing that our method is robust. Additionally we show the interannual variations of various monthly climate predictors (Figs 6c, 7c, 8c and 9c) and indices (Figs 6d, $7 d, 8 d$ and $9 d$ ) featuring pronounced correlation with the interannual ELA proxy variability.

For example, a significant correlation of the interannual ELA variability is present between SEN, NWN and Purogangri as well as between SEN and Shankangsham. A less significant correlation exists between SEN and Gurla Mandhata as well as between Targo Gangri and Gurla Mandhata (Table 3). But the time series do not all systematically correlate with each other. This is due not only to different reactions of the glaciers to climatic forcing but also to the fact that the interannual variability of the climatic predictors is not uniform across the TP. Even ROIs spatially close to each other show differences in the interannual variability of temperature and precipitation (Fig. 7c). The standard deviation of the interannual temperature is higher in the winter months (highest at Muztagh Ata; Fig. 6) whereas the precipitation has a higher interannual variability in the summer months (Table 1). Not only the amplitude of the variability but also its algebraic sign can be different in the same year across the TP, confirming the essential different climatic

Table 3. Pearson correlation coefficient $(r)$ for correlation between the interannual ELAs of all ROls. Significant correlations above the 0.1 level of significance are bold; correlations with $p<0.01$ are bold and underlined. MA: Muztagh Ata; GM: Gurla Mandhata; S: Surla; Sh: Shankangsham; TG: Targo Gangri

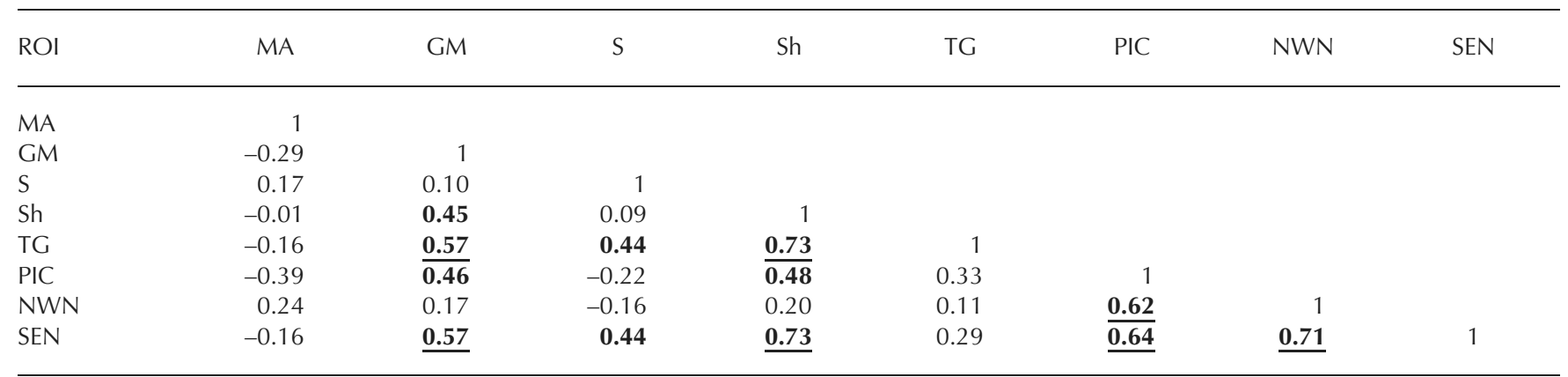


Muztagh Ata

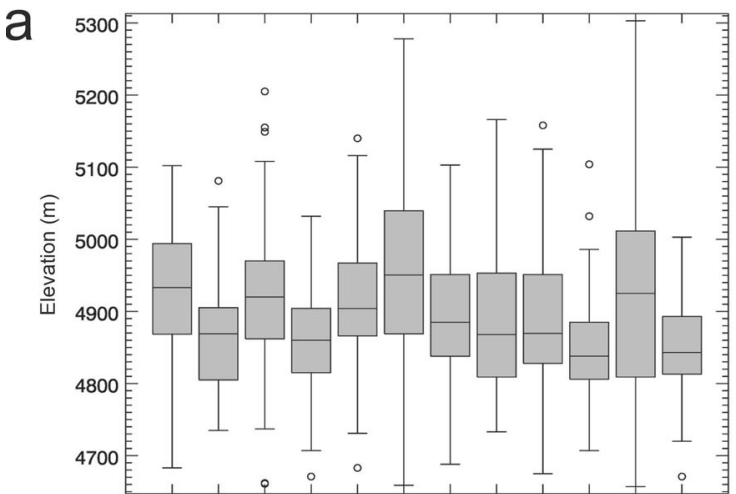

b

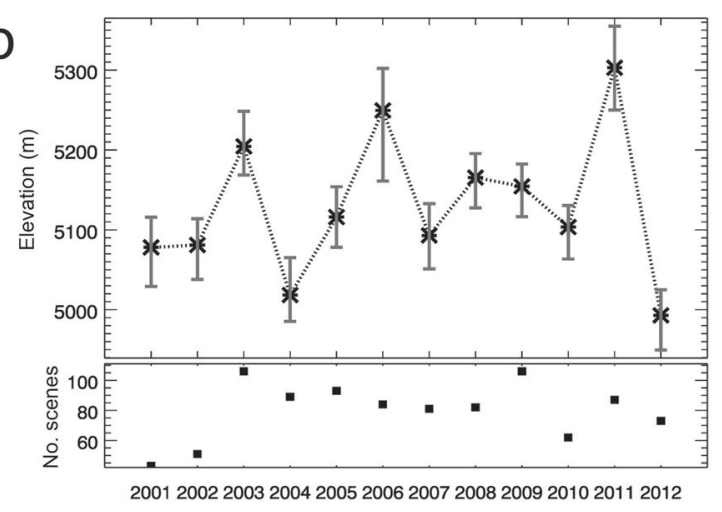

C
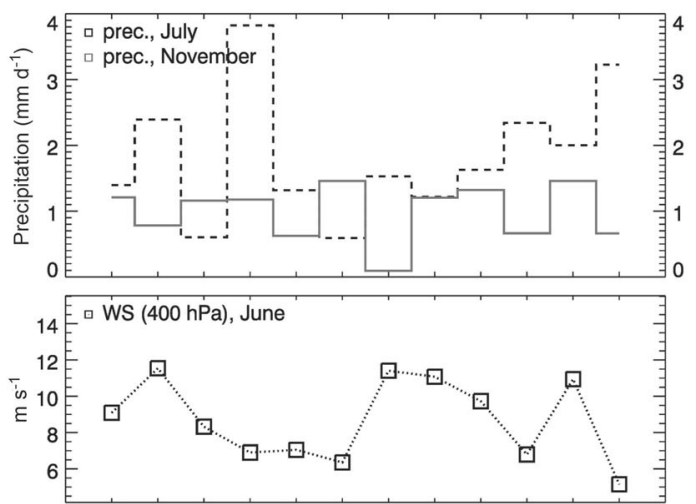

d
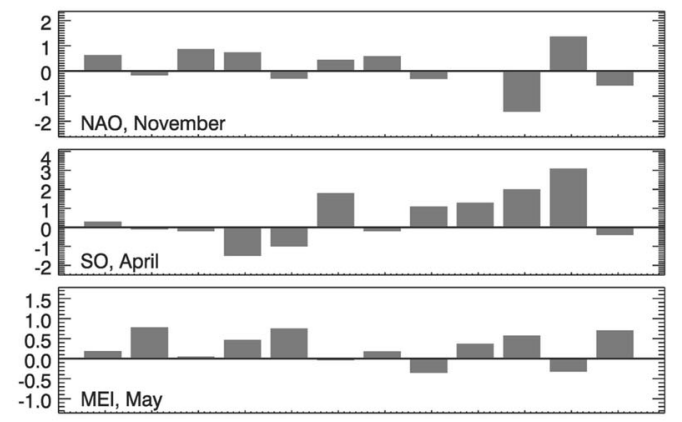

200120022003200420052006200720082009201020112012

\section{Gurla Mandhata}
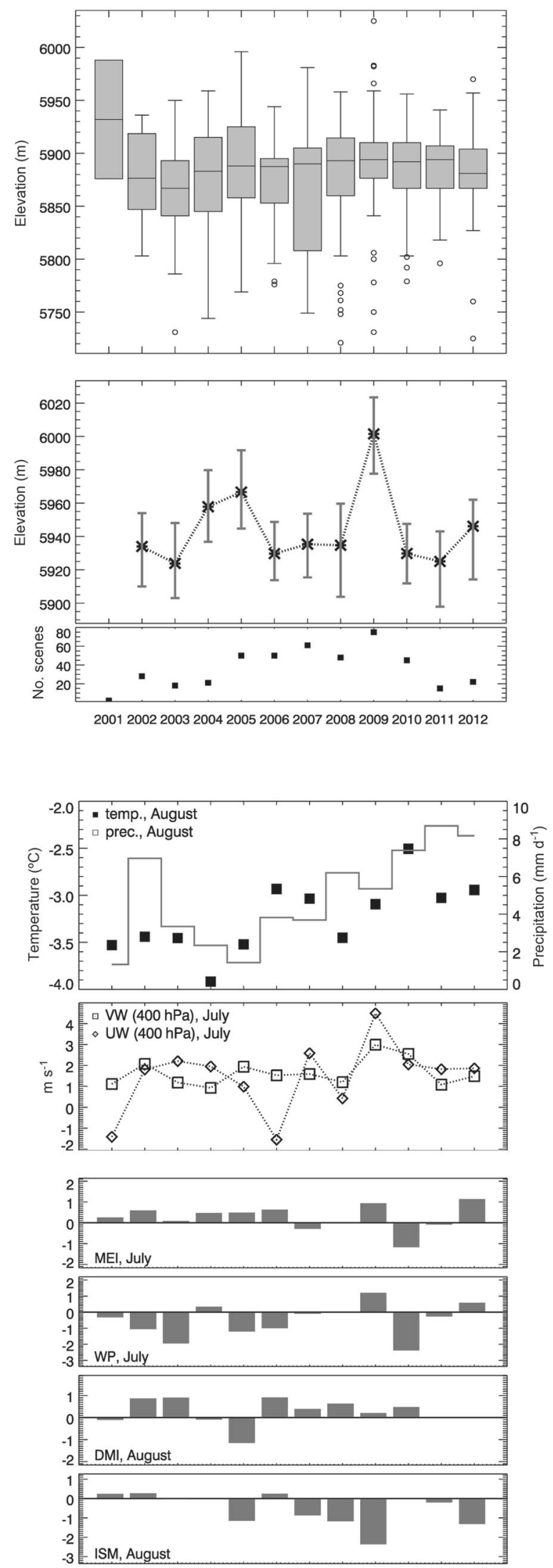

200120022003200420052006200720082009201020112012

Fig. 6. Results for Muztagh Ata and Gurla Mandhata. (a) Boxplot of the daily transient snowline calculated based on scenes with $\geq 45 \%$ valid pixels using the 13th percentile of the resulting snow pixels for each ROI from 1 July to 30 September for 2001-12. Each box encloses the 75th and 25th quartiles, with a bar representing the median, and extends to the minimum and maximum (error bars); outliers shown as circles. (b) Annual ELA calculated as highest weighted transient snowline altitude; error bars display uncertainty obtained by application of the 10th and 16th percentile (upper); number of scenes included in the calculation of the ELA (bottom). (c) Interannual variability of climatic predictors showing high correlation with the ELA. (d) Interannual variability of teleconnection indices that show high correlation with the ELA. 


\section{Surla}
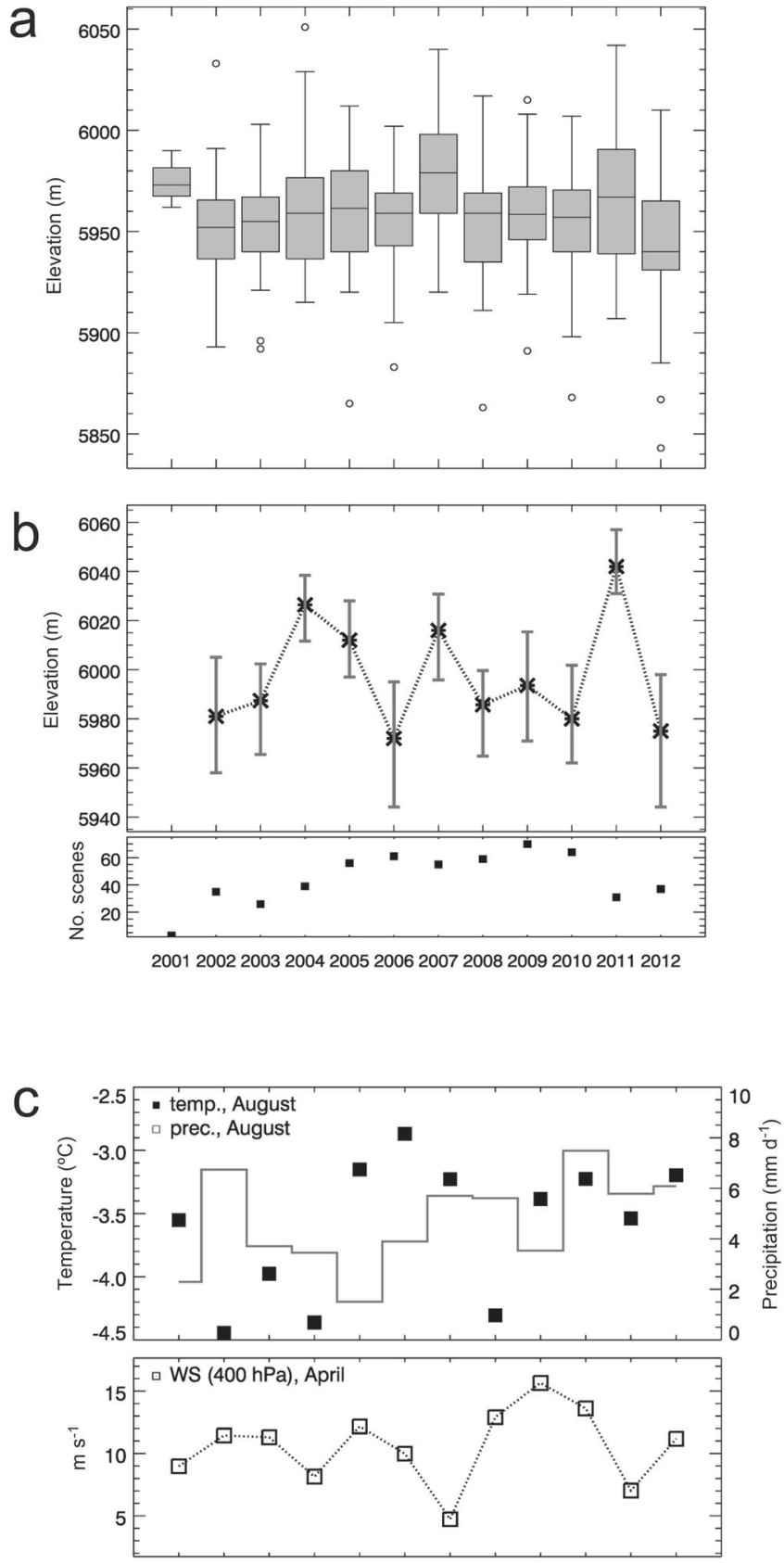

d
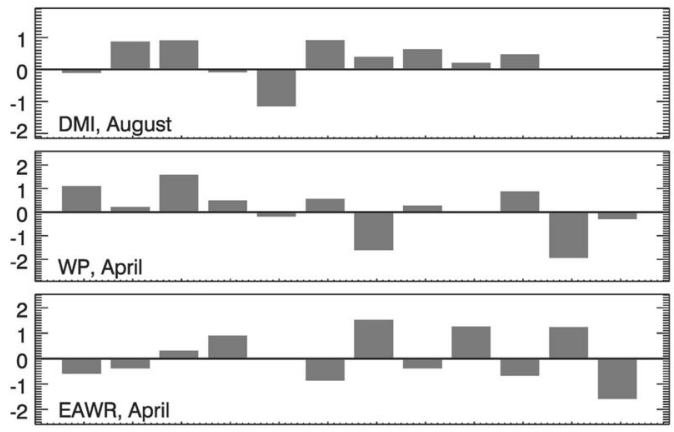

200120022003200420052006200720082009201020112012

Fig. 7. Same as Figure 6, but for Surla and Shankangsham.

patterns due to large-scale circulation and local factors. SEN and NWN show similar patterns of ELA proxies with a significant correlation $(r=0.71$; Table 3$)$. The mean annual ELA of SEN lies $10 \mathrm{~m}$ higher and the variation is
Shankangsham
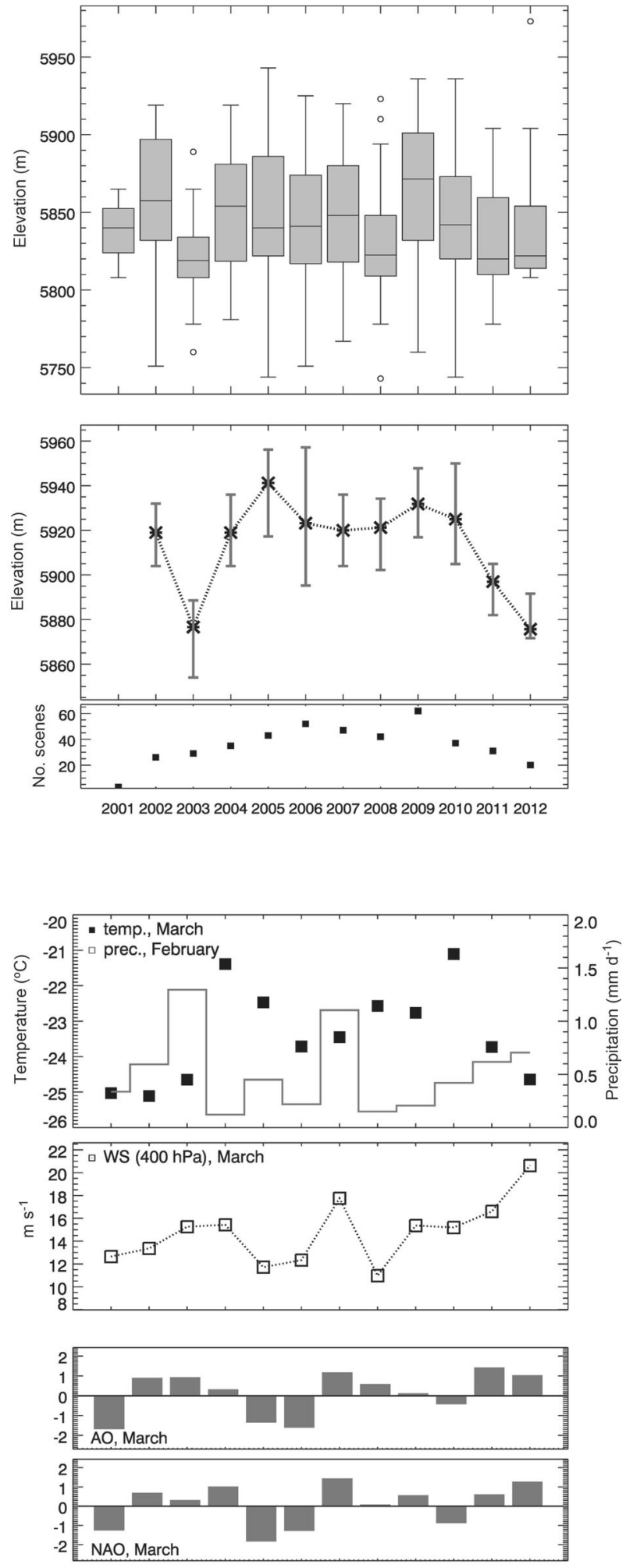

200120022003200420052006200720082009201020112012 less pronounced (Table 1). The three ROls in the central Trans-Himalaya show a similar progression in the interannual ELA, except for 2011 at Surla and 2007 at Shankangsham (Fig. $7 \mathrm{~b}$ ). The mean standard deviation of 
Targo Gangri
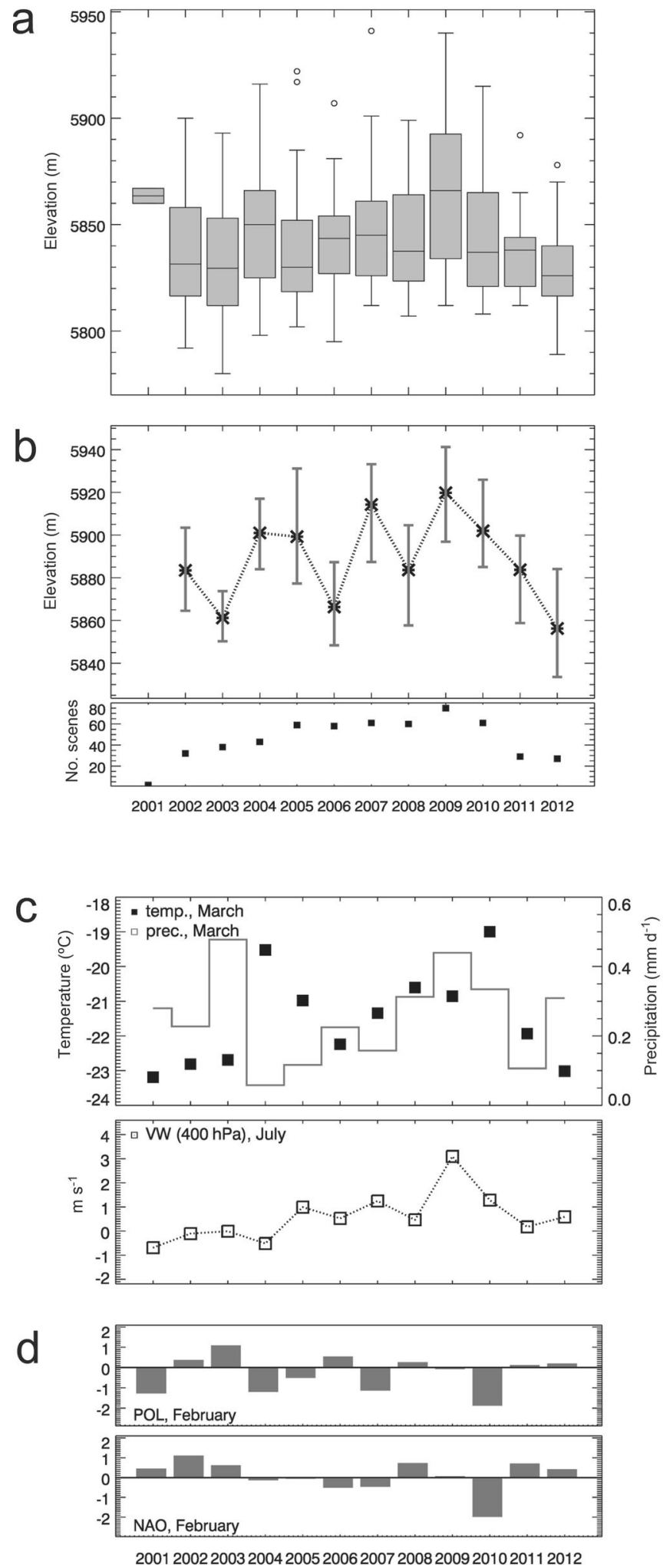

Fig. 8. Same as Figure 6, but for Targo Gangri and Purogangri.

the interannual ELA ranges between 21 and $29 \mathrm{~m}$ in all ROls, except for Muztagh Ata with $91 \mathrm{~m}$ (Table 1). The maximum difference in ELA between any two consecutive years is rarely $>50 \mathrm{~m}$ except for Muztagh Ata where this value exceeds $100 \mathrm{~m}$. The skill of the percentile approach in estimating the transient snowline altitude (and consequently the ELA) can be seen by comparing the median
Purogangri
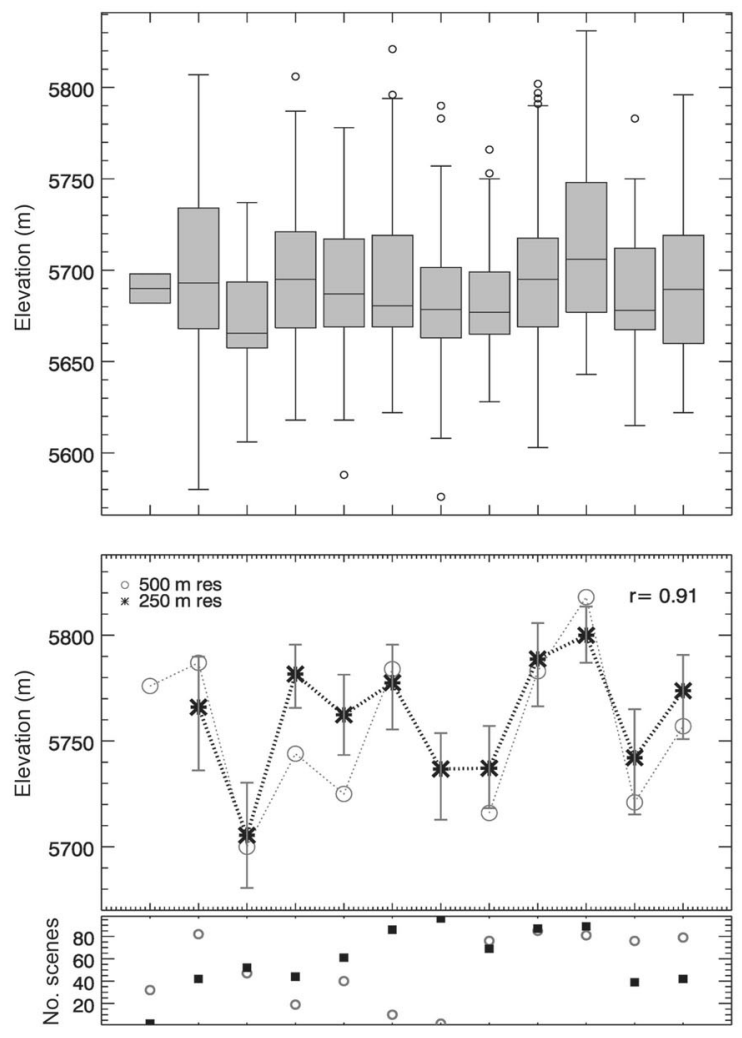

200120022003200420052006200720082009201020112012
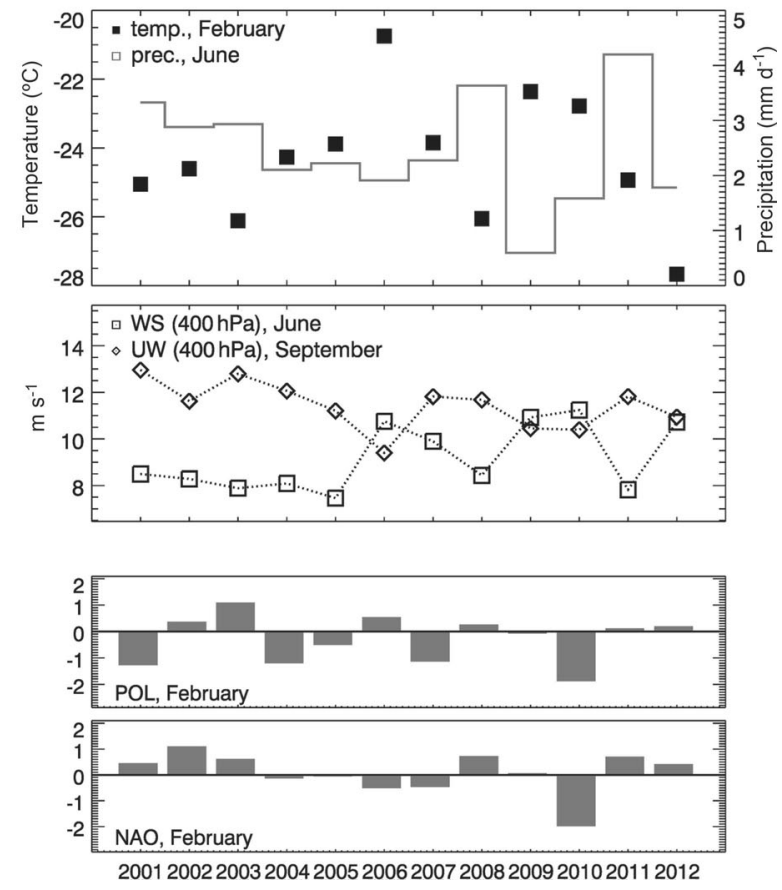

altitude of glaciers in each ROI (Table 2). Median glacier elevation is commonly used to infer the ELA (e.g. Braithwaite and Raper, 2010).

\section{Climate and ELA}

Correlations of annual ELA with climatic predictors from particular months are shown in Tables 4-8. Some 


\section{Nyainqentanglha (NWN)}
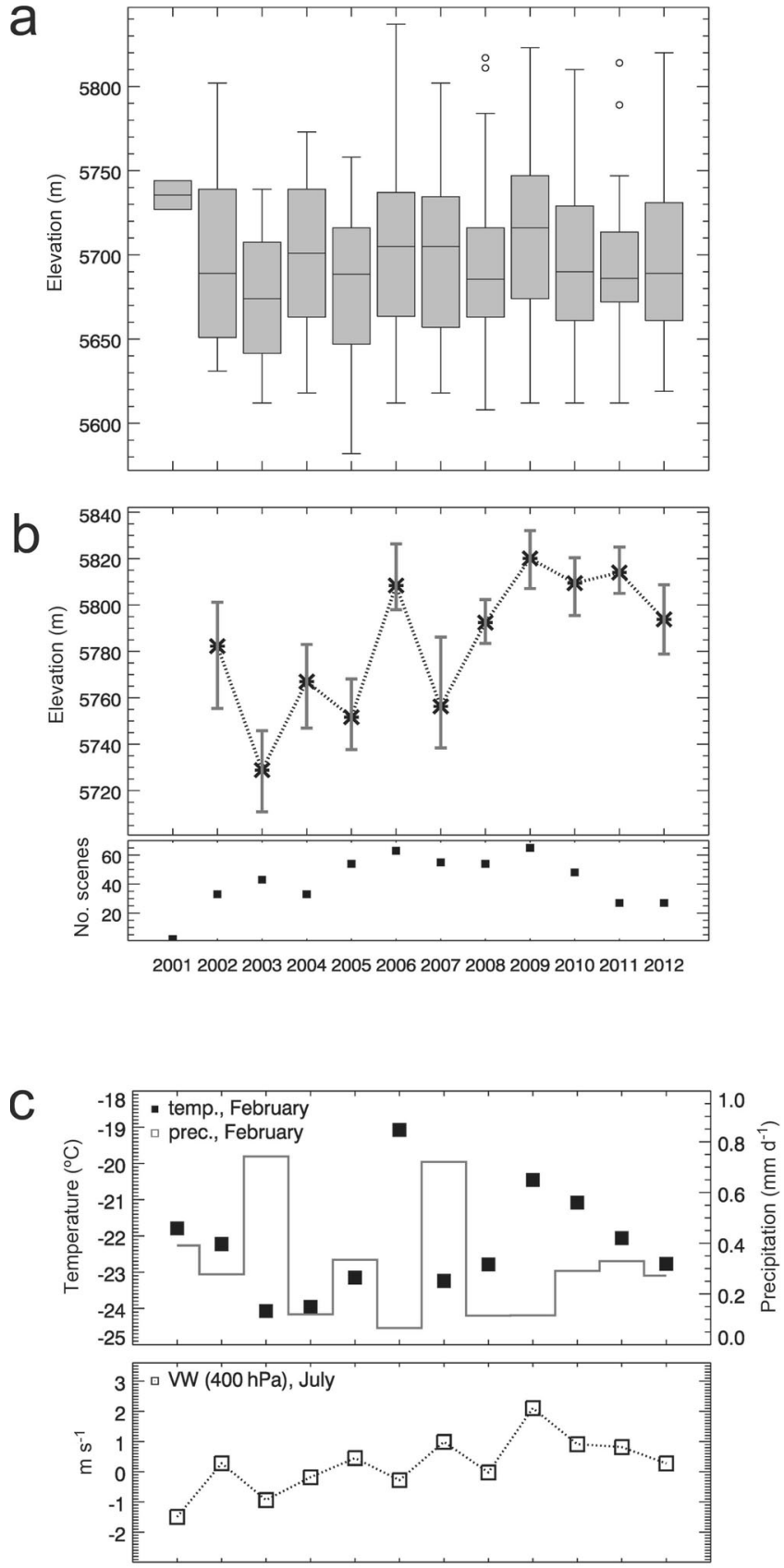

d

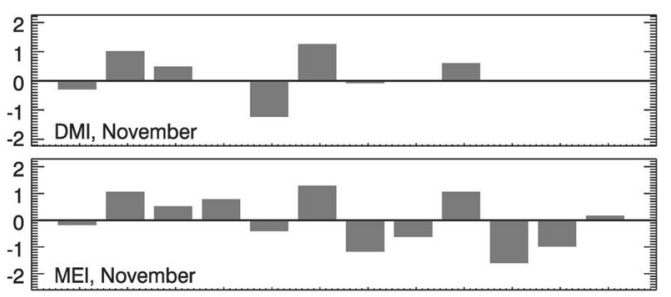

200120022003200420052006200720082009201020112012
Nyainqentanglha (SEN)
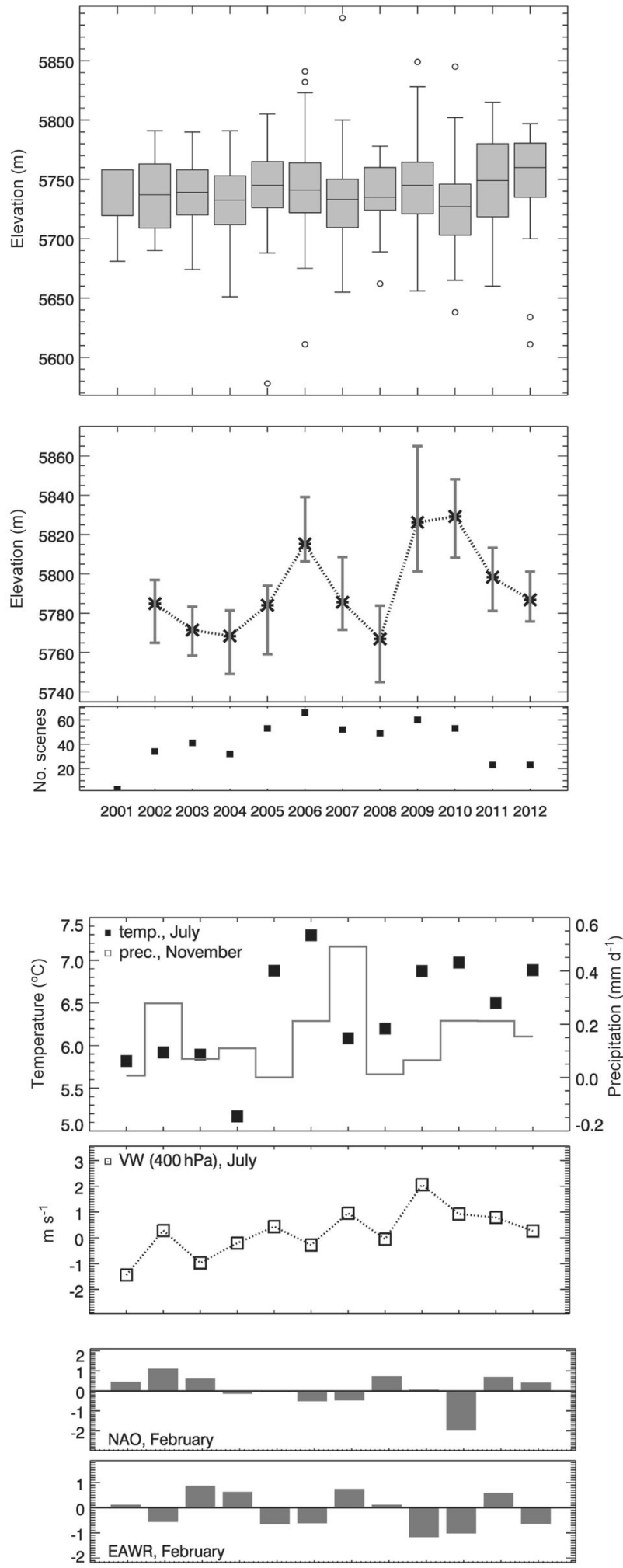

200120022003200420052006200720082009201020112012

Fig. 9. Same as Figure 6, but for NWN and SEN.

significantly correlated climatic predictors are shown in Figures $6 \mathrm{c}$ and $\mathrm{d}, 7 \mathrm{c}$ and $\mathrm{d}, 8 \mathrm{c}$ and $\mathrm{d}$ and $9 \mathrm{c}$ and $\mathrm{d}$.

At PIC stronger wind speed, easterly wind velocity and a negative phase of the $\mathrm{AO}$ are connected to a lower ELA ( $r=$ $-0.75, r=-0.74, r=0.69)$. A negative (positive) phase of the NAO (WP) in February increases the temperature $(r=-0.74$, $r=0.51$, which favours sublimation and raises the ELA $(r=0.65)$ (Table 4). The WP and POL form a quadrupole in February and March. A negative phase of the EAWR decreases the wind speed and raises the ELA $(r=-0.61)$ in February and June. The precipitation in June lowers the ELA $(r=-0.69)$, and increased wind speed at the $400 \mathrm{hPa}$ level might reduce the convective precipitation $(r=0.72)$. In July the temperature increases with southerly flow and raises the 
Table 4. Pearson correlation coefficient $(r)$ for correlation between the interannual ELA and climatic predictors as well as between interannual ELA and atmospheric climate indices for glaciers at PIC. Only relevant correlations are shown. Significant correlations above the 0.1 level of significance are bold; correlations with $p<0.01$ are bold and underlined. WS: wind speed, UW: zonal wind, VW: meridional wind

\begin{tabular}{|c|c|c|c|c|c|c|c|c|c|c|c|c|c|c|c|}
\hline & \multicolumn{3}{|c|}{ Nov } & \multicolumn{3}{|c|}{ Feb } & \multicolumn{3}{|c|}{ Jun } & \multicolumn{3}{|c|}{ Jul } & \multicolumn{3}{|c|}{ Sep } \\
\hline & WS (400) & UW (400) & $\mathrm{AO}$ & Temp. & $\mathrm{NAO}$ & EAWR & $\mathrm{POL}$ & WP & Temp. & Precip. & WS (400) & EAWR & Temp. & VW (400) & VW (300) \\
\hline PIC & -0.75 & -0.74 & 0.69 & 0.65 & $\underline{-0.74}$ & -0.61 & -0.64 & 0.51 & 0.52 & -0.69 & $\underline{0.72}$ & -0.64 & 0.61 & 0.51 & 0.59 \\
\hline
\end{tabular}

Table 5. Same as Table 4, but for the western Nyainqêntanglha range

\begin{tabular}{|c|c|c|c|c|c|c|c|c|c|c|c|c|c|c|c|c|c|c|c|}
\hline & \multicolumn{6}{|c|}{ Nov } & Dec & \multicolumn{3}{|c|}{ Jan } & \multicolumn{4}{|c|}{ Feb } & Jun & \multicolumn{4}{|c|}{ Jul } \\
\hline & Temp. & Precip. & $\begin{array}{l}\text { WS } \\
(400)\end{array}$ & $\begin{array}{l}\text { UW } \\
(400)\end{array}$ & DMI & MEI & Temp. & Temp. & Precip. & MEI & Temp. & Precip. & NAO & EAWR & Temp. & Temp. & $\begin{array}{l}\text { VW } \\
(400)\end{array}$ & $\begin{array}{l}\text { VW } \\
(300)\end{array}$ & $\begin{array}{l}\text { UW } \\
(300)\end{array}$ \\
\hline NWN & 0.74 & & & 0.35 & -0.58 & -0.67 & 0.71 & 0.34 & -0.43 & -0.64 & 0.78 & -0.70 & & -0.57 & & & 0.55 & 0.45 & -0.62 \\
\hline SEN & $\overline{0.35}$ & -0.67 & 0.65 & 0.62 & & & & 0.60 & -0.71 & & $\overline{0.85}$ & -0.30 & -0.68 & -0.69 & 0.63 & 0.73 & 0.64 & 0.77 & -0.58 \\
\hline
\end{tabular}

ELA $(r=0.78)$. In September a higher wind speed is connected to a lower ELA. Neckel and others (2013) found the mass budget of PIC to be close to equilibrium $\left(-44 \pm 15 \mathrm{~mm}\right.$ w.e. $\mathrm{a}^{-1}$ between 2000 and 2012) with slight thickening at higher and thinning at lower glacier elevations. This might be related to an increase in ablation due to higher temperatures and an increase in accumulation due to higher precipitation rates.

In the Nyainqêntanglha range a warmer and/or drier environment in November to February leads to a higher ELA, possibly due to enhanced sublimation (e.g. NWN Feb: $r=0.78, r=-0.70$; Table 5). At SEN a positive phase of the EAWR as well as of the NAO in February decreases the temperature and lowers the ELA $(r=-0.69, r=-0.68)$. The precipitation effect in June as described by Mölg and others (2013) is not seen in our data. In June and July the temperature increases the melt and raises the ELA (SEN: $r=0.67, r=0.73)$. In July the temperature increases with southerly flow and raises the ELA (SEN: $r=0.77$ ) whereas increased zonal wind seems to block this connection (SEN: $r=-0.58$ ). At NWN a positive phase of the MEI (EI Niño) and DMI (warmer western Indian Ocean) from October to February leads to a lower ELA.

At Targo Gangri the lowest interannual variability in ELA may be connected to the largest mean slope (Table 1). Steep slopes do not favour clear correlation results. Positive phases of NAO and POL in February are connected to lower ELA, and southerly flow in July to higher ELA (Table 6).

Shankangsham is the smallest ROI, with a mean slope of $9^{\circ}$, which makes the ELA proxy less reliable. Lower temperature and higher wind speed in March are connected to a lower ELA $(r=0.60, r=-0.63)$. A positive phase of the DMI, especially in June to August, is connected to a lower ELA. In July southerly flow is connected with higher ELA $(r=0.64)$ (Table 6).

Surla is the highest ROI, with a median height of $6100 \mathrm{~m}$ (Table 1). No connections to the temperature and the precipitation are apparent (Table 6). Only the April correlations show significance; strengthened wind speed in that month is connected to a lower ELA $(r=-0.63)$. Positive phases of the NAO and EAWR, which are here correlated with each other, lead to weaker wind speed in April and a lower ELA $(r=0.58, r=0.77)$. Also in April a positive phase of the WP is connected to a lower ELA $(r=-0.64)$. In July to September a connection to the DMI is visible $(r=-0.61$, -0.68), which hints at a monsoon coupling.

For Gurla Mandhata the small-scale climate directed by the surrounding valleys and their orientation might be more important than large-scale forcing. Still some correlations are noticeable, with many in July, even though they do not involve temperature and precipitation (Table 7). In April, enhanced wind speed raises the ELA $(r=0.61)$. Higher temperatures throughout winter and spring also tend to raise the ELA. In July the dominant southwest wind direction might not bring snowfall, which would explain the positive correlation of zonal and meridional wind $(r=0.52, r=0.55)$. A positive phase of the WP in July, which also prevails in August, is connected to a higher ELA $(r=0.60,0.58)$. Increased southeasterly flow in August is correlated with lowered ELA, but increased westerly winds correspond with

Table 6. Same as Table 4, but for glaciers in the Trans-Himalaya

\begin{tabular}{|c|c|c|c|c|c|c|c|c|c|c|c|c|c|c|c|c|c|c|c|}
\hline \multirow{2}{*}{\multicolumn{2}{|c|}{$\begin{array}{c}\text { Jan } \\
\text { Precip. }\end{array}$}} & \multicolumn{3}{|c|}{ Feb } & \multicolumn{5}{|c|}{ Mar } & \multicolumn{4}{|c|}{ Apr } & \multicolumn{2}{|l|}{ Jul } & \multicolumn{3}{|c|}{ Aug } & \multirow{2}{*}{$\begin{array}{l}\text { Sep } \\
\text { DMI }\end{array}$} \\
\hline & & Precip. & NAO & POL & Temp. & WS (400) & $\mathrm{NAO}$ & EAWP & $\mathrm{AO}$ & WS (400) & NAO & EAWR & WP & VW (400) & DMI & DMI & $\mathrm{AO}$ & PNA & \\
\hline S & & & & & & & & & & -0.59 & 0.58 & $\underline{0.77}$ & -0.64 & & -0.61 & -0.68 & -0.67 & & -0.68 \\
\hline $\begin{array}{l}\text { Sh } \\
\text { TG }\end{array}$ & -0.53 & -0.61 & -0.53 & -0.70 & $\begin{array}{l}0.60 \\
0.68\end{array}$ & -0.64 & -0.57 & -0.55 & -0.62 & & & & & 0.58 & -0.61 & $\begin{array}{l}-0.59 \\
-0.51\end{array}$ & & 0.70 & $\begin{array}{l}-0.44 \\
-0.50\end{array}$ \\
\hline
\end{tabular}


Table 7. Same as Table 4, but for Gurla Mandhata (GM)

\begin{tabular}{|c|c|c|c|c|c|c|c|c|c|c|c|c|c|c|c|}
\hline & \multirow{2}{*}{$\begin{array}{c}\text { Apr } \\
\text { UW (300) }\end{array}$} & \multirow{2}{*}{$\begin{array}{l}\text { Jun } \\
\text { MEI }\end{array}$} & \multicolumn{8}{|c|}{ Jul } & \multicolumn{4}{|c|}{ Aug } & \multirow{2}{*}{$\begin{array}{l}\text { Sep } \\
\text { MEI }\end{array}$} \\
\hline & & & VW (400) & VW (300) & UW (400) & UW (300) & DMI & WP & MEI & $\mathrm{AO}$ & DMI & WP & MEI & ISM & \\
\hline GM & 0.61 & 0.55 & 0.55 & 0.58 & 0.52 & 0.49 & -0.47 & 0.60 & 0.52 & -0.65 & -0.59 & 0.58 & 0.46 & -0.76 & 0.40 \\
\hline
\end{tabular}

an increased ELA $(r=0.55)$. A positive phase of the ISM, which is associated with a stronger monsoon, lowers the ELA $(r=-0.76)$. During June to September the monsoon corresponds to a lower ELA. Positive ENSO phases from June to September tend to result in increased ELA $(r=0.55$, $0.52,0.46,0.40)$.

At Muztagh Ata, only a few correlations are evident in summer, except for precipitation in June and July $(r=-0.52$, -0.67) (Table 8). Here the summer precipitation at higher elevation mainly falls in solid form (Huintjes, 2014). Increased precipitation in November and December, the months of minimum snowfall, lowers the ELA $(r=-0.67$, $-0.63)$. The wind speed, dominated by the westerlies, lowers the ELA ( $r=-0.86$, etc.). Additionally, positive phases of the NAO and $\mathrm{AO}$ enhance the wind speed, increase precipitation and lower the ELA $(r=-0.75,-0.53, r=-0.72$, -0.52). MEI is negatively correlated, especially in April and May when the precipitation maximum occurs. El Niño is connected to a lower ELA $(r=-0.64,-0.73)$. The SO shows the highest correlation in April, with a positive phase of the SO connected to a higher ELA $(r=0.73)$.

\section{DISCUSSION}

The reliability of the calculation of the transient snowline altitude depends largely on the initial quality of the data. MODIS imagery, with spatial resolution of $250 \mathrm{~m}$, is better able to cover glaciers of extensive plan form, such as ice caps, than valley glaciers. Increased glacier slope also decreases the richness of detail of a satellite picture. The precipitation regime affects the data coverage due to cloud cover. Additionally, a summer accumulation regime might make it harder to detect the highest transient snowline in the ablation period because of continuous snowfall. In this case the transient snowline is likely to reach its highest position in the post-monsoon months in September or early October (cf. Brun and others, 2015). We analysed the average annual cycle of albedo derived from the MODIS snow product data for Purogangri, Gula Mandhata and Targo Kangri, which shows its minimum within the period from July to September. For summer-accumulation-type glaciers the scene with the highest snowline is more likely to be missing due to cloud cover, in which case the ELA may be underestimated.

Regional ELAs have been used to infer regional mass balance (Pelto and Brown, 2012; Shea and others, 2013).
However, within the same ROI, the transient snowline elevation can vary across individual glaciers. For example, the transient snowline elevation calculated for 15 August 2010 at 18 PIC glaciers varies from 5544 to 5807 m. Despite this variation, the mass balances of different glaciers in a specific region often show very high correlations (Pelto and Brown, 2012; Gardelle and others, 2013). Temporal variability in the mean ELA is thus likely to be similar to that of the individual glaciers within a ROI.

The variability of the ELAs across the TP is equal neither in form nor in strength. Gurla Mandhata and Muztagh Ata have significantly higher interannual variation in precipitation than the other ROls. Muztagh Ata displays not only the highest intra-annual variability of the transient snowline but also the highest interannual variability of the ELA proxy and median of the transient snowline. The spring accumulation regime, with considerable precipitation throughout the year, distinguishes Muztagh Ata from the other ROls. From July to September Muztagh Ata receives the least precipitation (Table 1), so sudden severe precipitation could lead to the more pronounced difference in the snowline altitudes at Muztagh Ata. At Muztagh Ata the high interannual variability of the temperature in summer (Table 1) might indicate a temperature forcing even though it cannot be seen in mean monthly temperatures below melting point. From July to September, wind speed is the highest at Muztagh Ata, which favours sublimation (Table 1). Sublimation accounts for more than half the mass loss at Muztagh Ata, despite the high moisture content of the air (Huintjes, 2014). Another explanation for the strong ELA variability might be a higher mass turnover, since this increases the altitude range of glaciers (Table 1 ). The mean total amount of precipitation does not support this hypothesis (Table 1), but due to uncertainties in the absolute values of the HAR data and the very high portion of solid precipitation (Huintjes 2014), it may still be a plausible explanation.

The interannual variability of the ELA at Muztagh Ata shown in Yao and others (2012) between 2006 and 2010 agrees well with our results. Yao and others (2012) further reported a mean glacier retreat rate of $1.7 \mathrm{ma}^{-1}$ at Purogangri from 1974 to 2010 and approximated a corresponding mean annual ELA of $5735 \mathrm{~m}$, which is only $30 \mathrm{~m}$ below our mean ELA from 2001 to 2012 (Table 2). We confirm the higher ELAs in the continental-climate

Table 8. Same as Table 4, but for Muztagh Ata (MA)

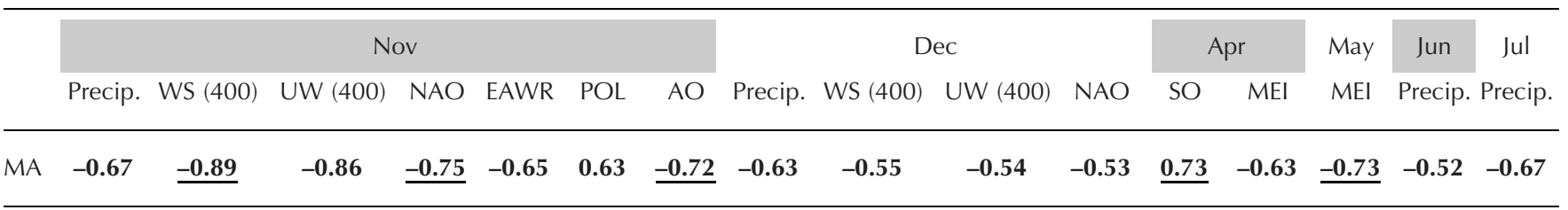


dominated interior, and the lower ELAs of glaciers in the Pamir, as stated by Yao and others (2012). The results in this study indicate an apparently negative mass-balance trend between 2003 and 2009 in the western Nyainqêntanglha range (Fig. 9) while Kääb and others (2015) report clearly negative mass balance for the eastern Nyainqêntanglha range for 2003-08.

When interpreting the correlations of the ELA with climatic predictors (Tables $4-8$ ) one has to bear in mind the limitation of the method, the short time-series duration and the possibility of unreliable correlations with climatic predictors. Furthermore, correlation does not imply causation. Nevertheless, high and significant correlations may well indicate climate-related forcing of the ELA proxy variability (Spieß and others, 2015). The absence of correlation, on the other hand, does not negate a physical connection to the evolution of the annual ELA proxy since the connection may be masked by other factors or may not show up as interannual variability.

We focused on monthly instead of seasonal correlations with climatic predictors. We conducted a correlation analysis between all considered predictors but they were not all shown in detail for clarity. Annual and seasonal climate indices were also examined. In general, the correlations with the monthly indices reach higher significance. In only three cases did the annual positive or negative phase seem to influence the ELA more than a monthly or seasonal connection. An annual positive phase of the WP leads to a higher ELA at Gurla Mandhata $(r=0.74)$. The annual EAWR is correlated to the ELA in the western Nyainqêntanglha range. At SEN the corresponding correlation coefficient $(r=-0.72)$ exceeds the monthly correlation in winter. At Shankangsham an annual positive phase of the DMI is connected to the interannual ELA $(r=-0.69)$.

The variation of glaciological responses to climatic forcings between ROls is very complex because not only the response but also the climatic driving forces are different even between spatially close ROls. There are strong differences in precipitation between regions and seasons on the TP (Curio and others, 2015). Teleconnections are even more complex to interpret when considering possible recycling of atmospheric moisture on the TP. Curio and others (2015) find that local moisture recycling provides $\sim 60 \%$ of the moisture on the TP. Also the snowfall in winter might have a storage function. Stored atmospheric moisture in snow might be recycled in the following warm season (Curio and others, 2015).

\section{CONCLUSION}

The examination of remotely sensed ELAs, dynamically downscaled meteorology, and climate indices in this study demonstrates the varying and complex glacier-climate relations across the Tibetan Plateau. In very general terms summer air temperature is most important for the central and eastern parts of the Tibetan Plateau while winter precipitation has much relevance for glaciers in the west of the plateau. However, when looking into the details of spatially varying influences of various factors on the interannual variance of the ELA it becomes obvious that individual patterns are much more complex.

The interannual variability of the ELA is less pronounced in summer-accumulation type glaciers, and differs in form and strength even between spatially close ROls.
Whereas increased westerly airflow in November enhances sublimation at PIC and Nyainqêntanglha, it is the driver of increased snowfall in the Pamirs, leading to a contrasting regional pattern of ELA variability.

Higher temperatures throughout winter and spring tend to raise the ELA at Muztagh Ata, Gurla Mandhata, Shankangsham and the Nyainqêntanglha range, even though temperatures are well below freezing point. This finding suggests that sublimation is favoured by rising temperatures even during periods with temperatures below freezing point, especially under arid conditions.

Strong southerly flow in July is connected to higher temperatures and is correlated with an increased ELA. Only at Muztagh Ata and Surla is this pattern not visible. Direct influence of the monsoon indicated through the ISM is only visible at Gurla Mandhata in August and NWN in July, but it is implied through the DMI at Gurla Mandhata, Surla and Shankangsham between June and September. Additionally, at Gurla Mandhata there might be a monsoon-ENSO coupling between June and September. An ENSO signal is traceable in the westernmost ROIs. El Niño in spring (summer) is connected to a lower (higher) ELA at Muztagh Ata (Gurla Mandhata). Whereas a positive phase of NAO in February or March is connected to higher wind speed and a lower ELA at PIC, SEN, Targo Gangri and Shankangsham, it is connected to lesser wind speed in April and a higher ELA at Surla.

Our study shows a wealth of interesting relations that can be obtained by the explication of remote-sensing data of the snowline related to climate forcing. To expand our study's spatial coverage, future research activities will be focused on ice fields along the northern fringe of the Tibetan Plateau. Most observational mass-balance studies to date aim at trends or temporally integrated glacier change of single glaciers and the relevant driving forces behind these changes. Our study, however, aims at interannual regional mean glacier mass-balance variability. It would be of interest to concentrate on single glaciers to improve the validation by comparing with mass-balance studies. The use of longer time series in the future and an enhanced correlation analysis may offer even more conclusive results with which to investigate climatic forcing mechanisms to glacier response on the TP.

\section{ACKNOWLEDGEMENTS}

This work is supported by the German Research Foundation (DFG) Priority Programme 1372, 'Tibetan Plateau: FormationClimateEcosystems' through the DynRG-TiP ('Dynamic Response of Glaciers on the Tibetan Plateau to Climate Change') project under codes SCHN 680/3-3 and SCHE 750/4-3 and by the German Federal Ministry of Education and Research (BMBF) Central Asia Monsoon Dynamics and Geo-Ecosystems (CAME) program, through the WET project ('Variability and Trends in Water Balance Components of Benchmark Drainage Basins on the Tibetan Plateau') under code 03G0804A. Fabien Maussion acknowledges support by the Austrian Science Fund (FWF project P22443-N21). The MOD02QKM and MYD02QKM data used in this study were acquired through the Level 1 and Atmosphere Archive and Distribution System (LAADS) at http://ladsweb.nascom. nasa.gov/ in Hierarchical Data Format (HDF). The acquisition of the MODIS data was supported by Frank Rüthrich, Philipps University of Marburg. The ASTER data product was obtained through the online Data Pool at the NASA 
Land Processes Distributed Active Archive Center (LP DAAC), US Geological Survey (USGS)/Earth Resources Observation and Science (EROS) Center, Sioux Falls, SD (https://lpdaac.usgs.gov/data_access). We thank Niklas Neckel (University of Tübingen), Nicolai Holzer (TU Dresden), Tobias Bolch (University of Zürich) and Ulrike Schinke (TU Dresden) for the acquisition of the glacier masks. All data analysis and graphics were realized and programmed in the Interactive Data Language (IDL), with the help of the WAVE and the Coyote IDL libraries. We thank Mauri Pelto, an anonymous reviewer, the scientific editor, Joseph Shea, and the chief editor Graham Cogley for valuable comments which greatly improved an earlier version of this work.

\section{REFERENCES}

Bolch T and 7 others (2010) A glacier inventory for the western Nyainqentanglha Range and the Nam Co Basin, Tibet, and glacier changes 1976-2009. Cryosphere, 4, 419-433 (doi: 10.5194/tc-4-419-2010)

Braithwaite RJ and Raper SCB (2010) Estimating equilibrium-line altitude (ELA) from glacier inventory data. Ann. Glaciol., 50(53), 127-132 (doi: 10.3189/172756410790595930)

Brun F and 8 others (2015) Seasonal changes in surface albedo of Himalayan glaciers from MODIS data and links with the annual mass balance. Cryosphere, 9(1), 341-355 (doi: 10.5194/tc-9341-2015)

Curio J, Maussion F and Scherer D (2015) A 12-year high-resolution climatology of atmospheric water transport over the Tibetan Plateau. Earth Syst. Dyn., 6, 109-124 (doi: 10.5194/esd-6-1092015)

Dumont $M$ and 6 others (2012) Linking glacier annual mass balance and glacier albedo retrieved from MODIS data. Cryosphere, 6(4), 2363-2398 (doi: 10.5194/tc-6-1527-2012)

Gardelle J, Berthier E, Arnaud Y and Kääb A (2013) Region-wide glacier mass balances over the Pamir-Karakoram-Himalaya during 1999-2011. Cryosphere, 7(6), 1885-1886 (doi: 10.5194/ tc-7-1263-2013)

Hall DK, Riggs GA and Salomonson VV (2006, updated daily) MODIS/Terra Snow Cover 5-min L2 Swath 500m V005, 1 July to 30 September, 2001 to 2012. National Snow and Ice Data Center, Boulder, CO. Digital media http://nsidc.org/data.docs/daac/ modis_v5/mod10_I2_modis_terra_snow_cover_5min_swath.gd. html

Hedin S (1909) Transhimalaya, 3 vols. F.A. Brockhaus, Leipzig

Huintjes E (2014) Energy and mass balance modelling for glaciers on the Tibetan Plateau - extension, validation and application of a coupled snow and energy balance model. (Doctoral dissertation, RWTH Aachen University) http://darwin.bth.rwth-aachen. de/opus3/volltexte/2014/5239/

Kääb A, Treichler D, Nuth C and Berthier E (2015) Brief Communication. Contending estimates of 2003-2008 glacier mass balance over the Pamir-Karakoram-Himalaya. Cryosphere, 9(2), 557-564 (doi: 10.5194/tc-9-557-2015)

Maussion F, Scherer D, Mölg T, Collier E, Curio J and Finkelnburg R (2014) Precipitation seasonality and variability over the Tibetan Plateau as resolved by the High Asia Reanalysis. J. Climate, 27(5), 1910-1927 (doi: 10.1175/JCLI-D-13-00282.1)
Mernild S, Pelto M, Malmros JK, Yde JC, Knudsen NT and Hanna E (2013) Identification of snow ablation rate, ELA, AAR and net mass balance using transient snowline variations on two Arctic glaciers. J. Glaciol., 59(216), 649-659 (doi: 10.3189/ 2013JoG12J221)

Mölg T, Maussion F and Scherer D (2013) Mid-latitude westerlies as a driver of glacier variability in monsoonal High Asia. Nature Climate Change (doi: 10.1038/ nclimate2055)

Neckel N, Braun A, Kropáček J and Hochschild V (2013) Recent mass balance of the Purogangri Ice Cap, central Tibetan Plateau, by means of differential X-band SAR interferometry. Cryosphere, 7(5) (doi: 10.5194/tc-7-1623-2013)

Pelto M and Brown C (2012) Mass balance loss of Mount Baker, Washington glaciers 1990-2010. Hydrol. Process., 26(17), 2601-2607 (doi: 10.1002/hyp.9453)

Pfeffer WT and 75 others (2014) The Randolph Glacier Inventory: a globally complete inventory of glaciers. J. Glaciol., $60(221)$, 537-551 (doi: 10.3189/2014JoG13J176)

Rupper S and Roe G (2008) Glacier changes and regional climate: a mass and energy balance approach. J. Climate, 21, 5384-5401 (doi: 10.1175/2008JCLI2219.1)

Shea JM, Menounos B, Moore RD and Tennant C (2013) An approach to derive regional snowlines and glacier mass change from MODIS imagery, western North America. Cryosphere, 7(2) (doi: 10.5194/tc-7-667-2013)

Shi Y and Liu S (2000) Estimation on the response of glaciers in China to the global warming in the 21 st century. Chinese Sci. Bull., 45(7), 668-672

Spieß M, Maussion F, Möller M, Scherer D and Schneider C (2015) MODIS derived equilibrium line altitude estimates for Purogangri ice cap, Tibetan Plateau, and their relation to climatic predictors (2001-2012). Geogr. Ann. A, 20, 1-17 (doi: 10.1111/ geoa.12102)

Styron RH and 6 others (2013) Miocene initiation and acceleration of extension in the South Lunggar rift, western Tibet: evolution of an active detachment system from structural mapping and (U-Th)/He thermochronology. Tectonics, 32(4), 880-907

Tian L, Zong J, Yao T, Ma L, Pu J and Zhu D (2014) Direct measurement of glacier thinning on the southern Tibetan Plateau (Gurenhekou, Kangwure and Naimona'Nyi glaciers. J. Glaciol., 60(223), 879-888 (doi: 10.3189/2014JoG14J022)

Town J (2008) The sliding snow of Tachab Kangri. Alp. J., 113(357), 84-92

Wu H, Wang N, Jiang X and Guo Z (2014) Variations in water level and glacier mass balance in Nam Co lake, Nyainqentanglha range, Tibetan Plateau, based on ICESat data for 2003-09. Ann. Glaciol., 55(66), 239-247 (doi: 10.3189/2014AoG66A100)

Yao T and 14 others (2012) Different glacier status with atmospheric circulations in Tibetan Plateau and surroundings. Nature Climate Change, 2(9), 663-667 (doi: 10.1038/nclimate1580)

Ye Q, Chen F, Stein A and Zhong Z (2009) Use of a multi-temporal grid method to analyze changes in glacier coverage in the Tibetan Plateau. Progr. Natural Sci., 19(7), 861-872 (doi: 10.1016/j.pnsc.2008.12.002)

Zhang Y, Fujita K, Ageta Y, Nakawo M, Yao T and Pu J (1998) The response of glacier ELA to climate fluctuations on High-Asia. Bull. Glacier Res., 16, 1-11

Zhang G, Xie H, Kang S, Yi D and Ackley SF (2011) Monitoring lake level changes on the Tibetan Plateau using ICESat altimetry data (2003-2009). Remote Sens. Environ., 115(7), 1733-1742 (doi: 10.1016/j.rse.2011.03.005) 